\title{
33. SPORES AND POLLEN FROM CENOZOIC SEDIMENTS OF THE FALKLAND PLATEAU, SITE 511, DEEP SEA DRILLING PROJECT LEG 71 ${ }^{1}$
}

\author{
Greta M. Bratzeva, Geological Institute of the U.S.S.R. Academy of Sciences, Moscow, U.S.S.R.
}

\begin{abstract}
Cenozoic sediments penetrated by Hole 511 in the southern part of the Atlantic Ocean (Falkland Plateau, Maurice Ewing Bank) were analyzed for palynomorphs. Upper Eocene and lower Oligocene palynoassemblages are characterized and correlated to synchronous palynoassemblages of similar character from South America, Australia, and New Zealand. The lower Oligocene assemblages show a close relationship to those of other Southern Hemisphere continents except Africa. They also contain reworked Permian and Mesozoic species.

The Eocene and early Oligocene climate of the study area was moderately warm and humid, very similar to the southern part of present-day New Zealand; a vertical zonation probably existed.
\end{abstract}

\section{INTRODUCTION}

Samples of Cenozoic sediments from Sites 511 and 512 were analyzed for palynomorphs. At Site 512, all 58 samples of middle Eocene and Miocene carbonate sediments were almost devoid of spores and pollen. In the Cenozoic sediments penetrated by Hole 511, 52 samples were analyzed over the interval from 3 to 185.5 meters. The 10 samples from the uppermost part of the section (Cores 1-3) contained no spores or pollens. In the lower part of the section (Cores 12-21), the spore and pollen content was also insignificant-analysis yielded no more than 50 specimens per sample. Analysis of 17 samples of sediment from the middle part of the section (Cores 4-12) found a relatively large number of spores and pollen, distributed as shown in Table 1.

Preservation of spores and pollen from the Cenozoic sediments at Site 511 is satisfactory, but many specimens are corroded and pitted.

The absence or negligible amounts of spores and pollen in some samples cannot yet be explained. It is clearly not related to lithological composition, which remains the same throughout the interval.

Stratigraphic subdivision of the Cenozoic sediments at Site 511 was accomplished by means of planktonic foraminifers, nannoplankton, radiolarians, and diatoms. The Paleocene-Eocene (Core 21), upper Eocene (Cores 17-20), and lower Oligocene (Cores 2-16) deposits penetrated are composed of diatomaceous oozes and clays.

\section{METHODS}

Sediments were treated with $10 \% \mathrm{HCl}$ to dissolve carbonates, disaggregated by boiling in $10 \% \mathrm{KOH}$, elutriated in a pyrophosphate solution $\left(\mathrm{NO}_{4} \mathrm{P}_{2} \mathrm{O}_{7}\right)$, separated in a heavy liquid $\left(\mathrm{CdF}_{2}\right)$ with specific gravity 2.2 , and treated by the acetolysis method. Release from silicates was carried out with cold HF. The residue obtained was covered with glycerine. Stable spores and pollen specimens were prepared from a glycerine emulsion on glycerine gel, numbered, and stored in the collection of the Paleofloristic Laboratory of the Geological Institute of the U.S.S.R. Academy of Sciences, No. GIN 3948.

\footnotetext{
${ }^{1}$ Ludwig, W. J., Krasheninnikov, v. A., et al., Init. Repts. DSDP, 71: Washington (U.S. Govt. Printing Office).
}

The study and microphotography were carried out using a Mikrofot D-16 biological microscope, magnification $7 \times 60$. Microphotographs of spores and pollen are presented in Plates 1-17.

\section{CHARACTERISTICS AND COMPARISON OF PALYNOASSEMBLAGES OF THE FALKLAND PLATEAU}

Only one specimen-a spore of Cyathidites sp. 1was present in Sample 511-21-1, 40-42 cm (PaleoceneEocene sediments).

\section{Upper Eocene}

Eleven samples were analyzed from upper Eocene sediments (Cores 17-20): 511-20,CC; 511-20-3, 34-36 $\mathrm{cm}$; 511-20-2, 34-36 cm; 511-20-1, 34-36 cm; 511-18,CC; 511-18-2, 34-36 cm; 511-18-1, 34-36 cm; 511-17,CC; $511-17-3,17-19 \mathrm{~cm} ; 511-17-2$, 96-98 cm; 511-17-1, $96-98 \mathrm{~cm}$. The examination showed very small numbers of spores and pollen, from 10 to 40 specimens per sample. Sample 511-18-2, 34-36 cm was the most productive (39 specimens). Despite the small number of isolated microfossils, all samples contain spores of diverse systematic composition: Leiotriletes microadriennis, Cyathidites minor, Stereisporites antiquasporites, Leptolepidites verrucatus, Gleicheniidites senonicus, Cingutriletes australis, Lygodiidites sp., Cyathidites sp. 1, Deltoidospora sp., Concavissimisporites sp., Osmundacidites $\mathrm{sp} .$, Lycopodiumsporites $\mathrm{sp}$., Trilites $\mathrm{sp} .1$, and Form sp. 1 (item 61 in the list of species). Equal amounts of gymnosperm and angiosperm plant pollen are present within the assemblage. Gymnosperms are represented by three genera (Podocarpidites marwickii, Dacrydium cupressinum, and Phyllocladidites mawsonii), angiosperms by two (Nothofagidites asperus, N. sp. 2, Tricolpites $\mathrm{sp} .3$ ).

Many species of this palynoassemblage, such as $G$. senonicus, Leiotriletes microadriennis, Cingutriletes australis, Podocarpidites marwickii, Phyllocladidites mawsonii, D. cupressinum, and $N$. asperus, are representative of Eocene deposits in Argentina (Freile, 1972; Archangelsky, 1972, 1973a, b; Archangelsky and Romero, 1974b; Menendes and Caccavari de Filice, 1975; 


\section{G. M. BRATZEVA}

Table 1. Quantitative chart of spores and pollen in lower Oligocene sediment samples from Hole 511.

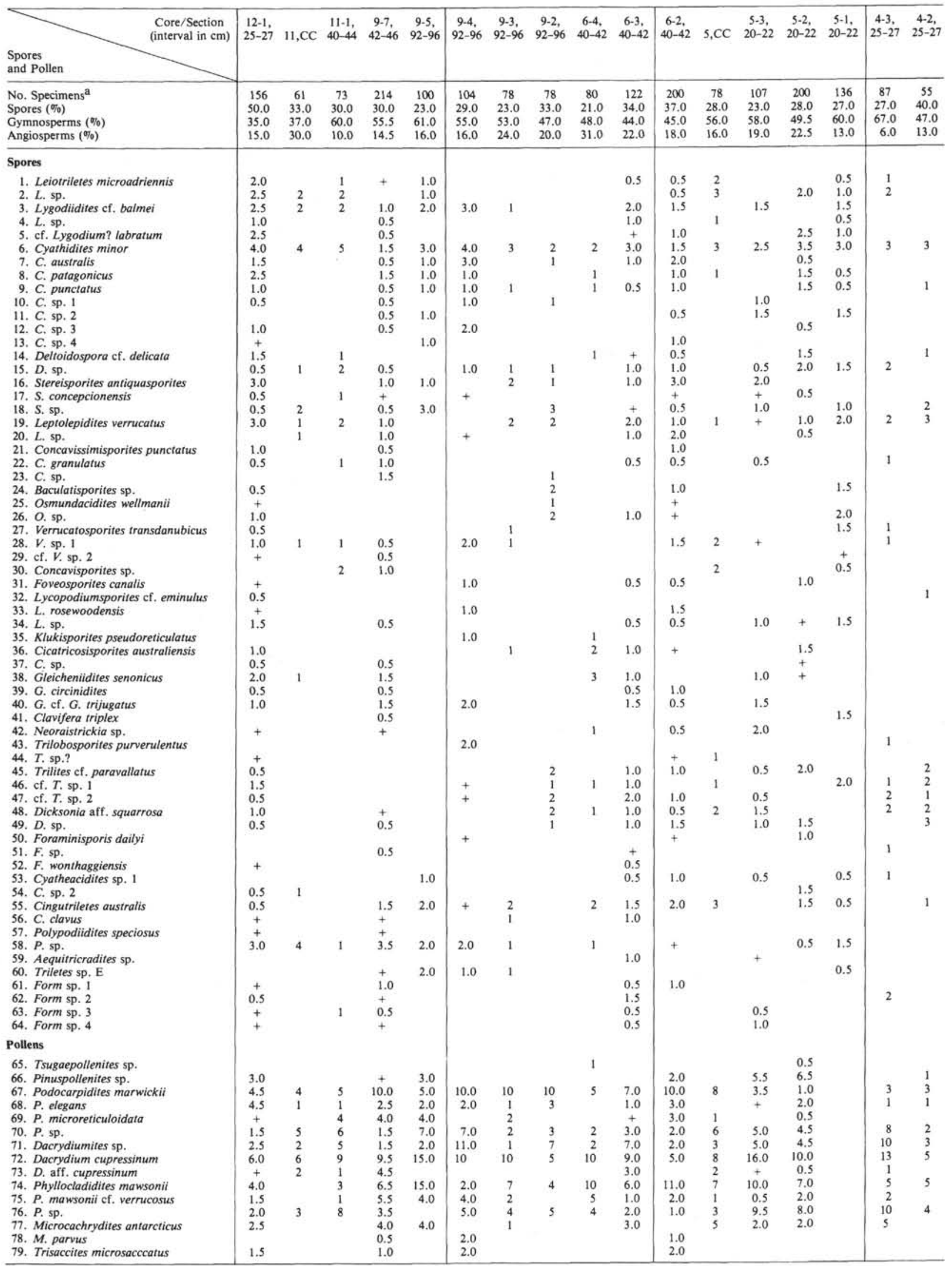

Note: + indicates that content is $<0.5 \%$.

a Where total $N$ is $<100$, column entries specify no. specimens found; for a total $\mathrm{N}>100$, column entries are percentages. 
Table 1, (Continued).

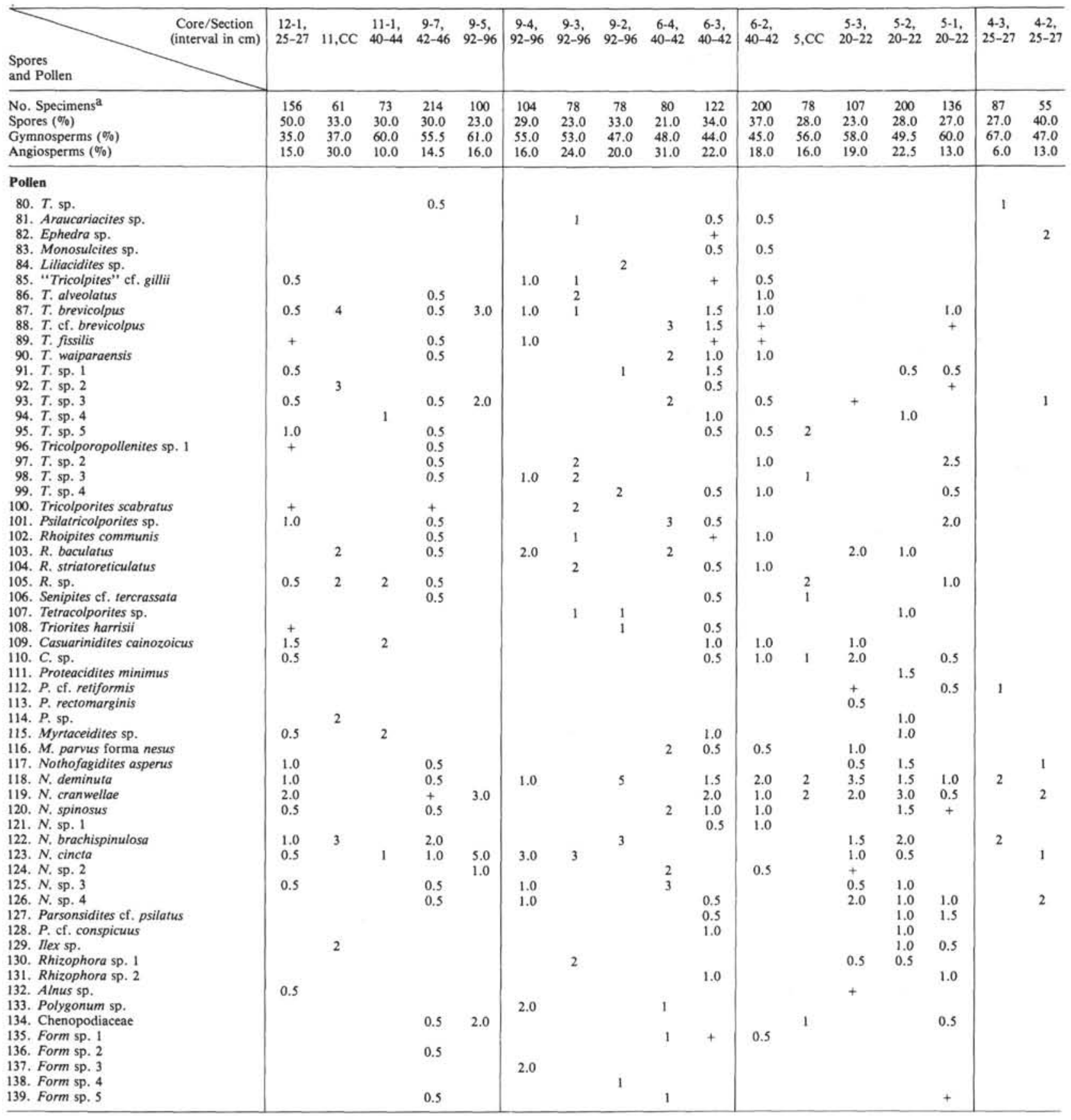

Romero, 1977), Chile (Takahashi, 1977), New Zealand (Couper, 1953, 1960), and Australia (Cookson, 1964). The rest of the forms, mainly spores, are widely distributed in both the Mesozoic and the Cenozoic deposits of the Southern Hemisphere. Archangelsky (1973b) showed that in Eocene palynoassemblages from $\mathrm{Ar}$ gentina Nothofagidites and gymnosperm pollen (Podocarpidites, Dacrydiumites, and Phyllocladidites) were predominant. He noted that some Eocene horizons were rich in spores. The Eocene climate in the region of $\mathrm{Ar}$ gentina was moderate and humid. The composition of upper Eocene palynoassemblages at Site 511 testifies to a relatively humid, warm, temperate climate.
Palynological data do not show an abrupt change at the upper Eocene/lower Oligocene boundary, but appreciable change is apparent somewhat higher at 108.5 meters, in lower Oligocene sediments. It is difficult to locate this change precisely, because no samples from 109.5-128.5 meters (Cores 13-14) were available for study (core recovery $3.3 \%$ and $0.5 \%$, respectively).

\section{Oligocene}

Over the interval from 3 to 147.5 meters (Cores 5111-16), Hole 511 sediments belong to the lower Oligocene. In this interval, 37 samples were analyzed: 7 proved barren, 13 contained small amounts of pollen 
and spores (up to 50 specimens), and 17 had from 50 to 215 specimens.

Four samples (511-16,CC; 511-16-2, 33-35 cm; 511$16-1,33-35 \mathrm{~cm}$; $511-15-1,28-30 \mathrm{~cm}$ ) were analyzed at the base of the lower Oligocene section, from 128.5 to 147.5 meters (Cores 15-16).

The numbers of spores and pollen in the samples were very small; they are most abundant in Sample 511-16-2, 33-35 cm. As in the previous palynoassemblage, spores predominate: Cyathidites patagonicus, $C$. minor, Gleicheniidites senonicus, Cingutriletes australis, Stereisporites antiquasporites, Leptolepidites sp., Osmunda sp., and Polypodiidites sp. Gymnosperm pollens were few (Pinuspollenites, Podocarpus sp., Dacrydium cupressinum, Phyllocladidites mawsonii). Numbers and diversity of angiosperm plants increase somewhat: Nothofagidites deminuta, $N$. sp. 2, Proteacidites sp., Casuarinidites sp., Chenopodiaceae, Tricolpites $\mathrm{cf}$. brevicolpus, $T$. fissilis, $T$. sp. 3 .

In the superjacent sediments, beginning at Sample 511-12-2, 25-27 cm and representing the interval from 6-108.5 meters, the ratio of the major groups in the palynoassemblage (spores, gymnosperms, and angiosperms) changes sharply. Pollens of gymnosperm plants are most abundant $(35-60 \%)$, spores are second (21$50 \%$ ), and then pollen of angiosperm plants (10-31\%). This ratio remains the same throughout the rest of the lower Oligocene section (see Table 1).

Spores were the most diverse taxonomically, with 27 genera and 64 species identified. These consisted primarily of Leiotriletes microadriennis, cf. Lygodium? labratum, Cyathidites patagonicus, Deltoidospora cf. delicata, Stereisporites concepcionensis, Verrucatosporites transdanubicus, Lycopodiumsporites cf. eminulus, Neoraistrickia sp., Trilites cf. paravallatus, Cingutriletes australis, and Polypodiidites speciosus. These have been described from Cenozoic deposits, mostly of Paleogene age, in Argentina (Archangelsky, 1972), Chile (Takahashi, 1977), Western Europe (Krutzsch, 1959; Kedves, 1973), North America (Frederiksen, 1973) and from the Neogene of Africa (Sah, 1967). The spores Cyathidites minor, C. australis, S. antiquasporites, and Leptolepidites verrucatus are distributed worldwide in Mesozoic and Cenozoic sediments. Some spores, such as Gleicheniidites senonicus and Clavifera triplex, are present both in Paleogene (Archangelsky, 1972, 1973a) and Cretaceous sediments (Dettmann and Playford, 1969; Burger, 1976). Dicksonia aff. squarrosa is distributed in New Zealand from Maestrichtian to Recent times (Couper, 1960). The majority of species (Concavissimisporites punctatus, C. granulatus, Osmundacidites wellmanii, Foveosporites canalis, Klukisporites pseudoreticulatus, Cicatricosisporites australiensis, Gleicheniidites cf. G. trijugatus, Foraminisporis wonthaggiensis, $F$. dailyi, Cingutriletes clavus, Trilobosporites purverulentus, and Lycopodiumsporites rosewoodensis) are characteristic of the Cretaceous of Australia (Dettmann, 1963; Burger, 1974, 1976; Playford et al., 1975; Dettmann and Playford, 1969), New Zealand (Couper, 1960), England (Stover, 1964; Playford, 1971), and Canada (Pocock, 1964; Vagvolgyi and Hills, 1969).
The presence, in the lower Oligocene palynoassemblage, of spores that, judging by the data in the literature, are not peculiar to Cenozoic deposits can be explained in one of two ways: either the plants to which these spores belonged existed in the flora of the Southern Hemisphere longer than previously recognized, or the spores have been reworked from older deposits. In degree of preservation, however, these spores do not differ from the Cenozoic spores. Clearly redeposited forms are present in the palynoassemblage-for instance, striate pollens of conifers, characteristic of Permian and Triassic sediments, and dark brown spores, possibly redeposited from Mesozoic sediments. Microphotographs of some of these are given in Plate 17.

In all samples from these upper cores, the composition of the pollen assemblage derived from gymnosperm plants is very similar and is close to that of the gymnosperm pollen from the underlying Oligocene and upper Eocene sediments. In addition, the palynoassemblage in this upper interval is most diverse taxonomically; it contains 10 genera and 18 species of gymnosperm plant pollen. Predominant are Podocarpidites marwickii, $P$. microreticuloidata, Dacrydium cupressinum, D. aff. cupressinum, Phyllocladidites mawsonii, $P$. mawsonii $\mathrm{cf}$. verrucosus, and Microcachrydites antarcticus. There are small amounts of $M$. parvus, Trisaccites microsaccatus, Pinuspollenites, and Ephedra sp., and single grains of Tsugaepollenites and Araucariacites. All the above species, except $M$. parvus, are representative of the Cretaceous and Tertiary of the Southern Hemisphere. $M$. par$v u s$ is distributed in Oligocene, Neogene, and Pleistocene deposits of New Zealand (Couper, 1960).

The pollen composition of angiosperm plants in the palynoassemblage is relatively diverse-24 genera, 57 species. Nothofagites pollens belonging to three groups (menziesii, brassi, and fusca) are predominant. Among them are: $N$. asperus, $N$. deminuta, $N$. cranwellae, $N$. spinosus, $N$. brachispinulosa, $N$. cincta. These are widespread in Cenozoic sediments of New Zealand (Couper, 1960), Australia (Cookson, 1958), Argentina (Archangelsky and Romero, 1974a,b; Menendes and Caccavari de Filice, 1975; Romero, 1977), and the Antarctic (Cranwell, 1964). In the recent flora of New Zealand, Australia, and South America, there are no representatives of the genus Nothofagidites of the menziesii and brassi groups, which are known only in the flora of New Guinea and New Caledonia. The predominance of Nothofagidites is peculiar to Tertiary deposits of New Zealand and Australia (Couper, 1960). Almost all samples contain pollen of the genera Causarinidites, Psilatricolporites, Rhoipites, Tricolporopollenites, and Tricolpites. Pollen of the genera Proteacidites, Myrtaceidites, and Rhizofora occur in much smaller amounts. Very typical pollens of Parsonsidites cf. psilatus, Ilex, Alnus, Polygonum, and Chenopodiaceae were observed in some of the samples. Pollens of the angiosperms from the lower Oligocene sediments at Site 511 are, therefore, peculiar to Paleogene deposits of New Zealand (Couper, 1953, 1960), Australia (Cookson, 1958, 1964), and South America (Archangelsky, 1973a, b; Romero, 1977; Takahashi, 1977). 
Thus, the lower Oligocene palynoassemblage of Site 511 is very similar to the palynoassemblages from Paleogene deposits of all Southern Hemisphere continents except Africa, and to the palynoassemblage found in Oligocene and lower Miocene sediments penetrated by Hole 270, DSDP Leg 28 (Kemp, 1974).

\section{CONCLUSIONS}

The composition of the palynoassemblages suggests that during the accumulation of Paleogene sediments on the Falkland Plateau, the nearest continent (or islands) was covered by forest vegetation similar in composition to the Recent vegetation of New Zealand, and especially of its southern island. In the northern part of this island there are at present subtropical forests consisting of conifers (Podocarpus, Dacridium) and broad-leaved plants, and in the southern part subantarctic forests with various types of Nothofagus (Campbell, 1948). The wide distribution of Nothofagus indicates that the Eocene and Oligocene climate in the area of the Falkland Plateau was moderately warm and humid. It is likely that vertical zonality existed as well.

During the Paleogene, Argentina (Romero, 1977) and Australia (Cranwell, 1964) also supported forest vegetation similar to that existing today in New Zealand.

This study of the composition of the late Eocenelower Oligocene palynoassemblages of Site 511 in conjunction with the data of other researchers (Cranwell, 1964; Romero, 1977) has enabled us to establish a close relationship among floras of the southern parts of South America, New Zealand, Antarctica, and Australia for the Paleogene period. The connection between South America and New Zealand was made via Antarctica and Australia, which were much closer together at that time. Such a relationship is evidenced by the present-day forests in which Nothofagus is present and which cover the southern margins of Argentina, Chile, Australia, and New Zealand. On the Antarctic continent, they have been destroyed by glaciation.

\section{TAXONOMIC LIST}

In the numbered list of taxa that follows, the geological distribution of previously defined species is given. The distribution of the taxa is presented in Table 1.

Anteturma SPORITES H. Potonié, 1893 Turma TRILETES Reinsh, 1881, emend. R. Potonié and Kremp, 1954

Subturma AZONOTRILETES Luber, 1935, emend. Dettmann, 1963 Infraturma LAEVIGATI Bennie and Kidstone, 1886, emend., R. Potonié and Kremp, 1954

Genus LEOTRILETES Naumova, 1937, emend. R. Potonié and Kremp, 1954

1. Leiotriletes microadriennis Krutzsch, 1959 (Plate 1, Fig. 1). Middle Eocene of DDR (Krutzsch, 1959); Eocene of Chile (Takahashi, 1977).

2. Leiotriletes sp. (Plate 1, Fig.4).

Genus LYGODIDITES Pocock, 1964

3. Lygodiidites cf. balmei Pocock, 1964 (Plate 1, Figs. 2-3). Middle and upper Albian of Canada (Pocock, 1964).

4. Lygodiidites sp. (Plate 1, Fig. 5).

\section{Genus LYGODIUM Swartz, 1801}

5. cf. Lygodium? labratum Frederiksen, 1973 (Plate 1, Fig. 6). Upper Eocene of Mississippi (Frederiksen, 1973).

\section{Genus CYATHIDITES Couper, 1953}

6. Cyathidites minor Couper, 1953 (Plate 1, Figs. 8-11). Worldwide distribution in Mesozoic and Cenozoic sediments.

7. Cyathidites australis Couper, 1953 (Plate 1, Fig. 12). Worldwide distribution in Mesozoic and Cenozoic sediments.

8. Cyathidites patagonicus Archangelsky, 1972 (Plate 2, Fig. 1). Eocene of Argentina (Archangelsky, 1972).

9. Cyathidites punctatus (Delcourt and Sprumont), Delcourt et al., 1963 (Plate 2, Fig. 2). Lower Cretaceous of Australia (Burger, 1974).

10. Cyathidites sp. 1 (Plate 2, Fig. 3).

11. Cyathidites sp. 2 (Plate 2, Fig. 4).

12. Cyathidites sp. 3 (Plate 2, Figs. 5-6).

13. Cyathidites sp. 4 (Plate 2, Fig. 7).

\section{Genus DELTOIDOSPORA Miner, 1935, emend.} R. Potonié, 1956

14. Deltoidospora cf. delicata Sah, 1967 (Plate 2, Figs. 8-9). Upper Neogene of Burundi (Sah, 1967).

15. Deltoidospora sp. (Plate 2, Fig. 10).

\section{Genus STEREISPORITES Pflug, 1953}

16. Stereisporites antiquasporites (Wilson and Webster), Dettmann, 1963 (Plate 3, Fig. 1). Worldwide distribution in Mesozoic and Cenozoic sediments.

17. Stereisporites concepcionensis Takahashi, 1977 (Plate 3, Fig. 2). Eocene of Chile (Takahashi, 1977).

18. Stereisporites sp. (Plate 3, Fig. 3).

\section{Infraturma APICULATI Bennie and Kidstone, 1886, emend. R. Potonié, 1956}

Genus LEPTOLEPIDITES Couper, 1953

19. Leptolepidites verrucatus Couper, 1953 (Plate 3, Fig. 4). Worldwide distribution in Mesozoic and Cenozoic sediments.

20. Leptolepidites sp. (Plate 3, Fig. 5)

\section{Genus CONCAVISSIMISPORITES}

Delcourt and Sprumont, emend. Delcourt et al., 1963

21. Concavissimisporites punctatus (Delcourt and Sprumont), Pocock, 1964 (Plate 3, Fig. 6). Middle and upper Albian of Canada (Pocock, 1964), Cretaceous sediments of England (Stover, 1964); Lower Cretaceous of Canada (Vagvolgyi and Hills, 1969).

22. Concavissimisporites granulatus Pocock, 1964 (Plate 3, Fig. 7). Middle and upper Albian of Canada (Pocock, 1964).

23. Concavissimisporites sp. (Plate 3, Fig. 8).

\section{Genus BACULATISPORITES}

Thomson and Pflug, 1953

24. Baculatisporites sp. (Plate 3, Fig. 9).

\section{Genus OSMUNDACIDITES Couper, 1953}

25. Osmundacidites wellmanii Couper, 1953 (Plate 3, Fig. 10). Triassic to middle Senonian of New Zealand (Couper, 1960).

26. Osmundacidites sp. (Plate 3, Fig. 11).

\section{Genus VERRUCATOSPORITES Thomson and Pflug, 1953}

27. Verrucatosporites transdanubicus Kedves, 1973 (Plate 4, Fig. 1). Lower and middle Eocene of Hungary (Kedves, 1973).

28. Verrucatosporites sp. 1 (Plate 4, Fig. 2).

29. cf. Verrucatosporites sp. 2 (Plate 4, Fig. 4).

\section{Genus CONCAVISPORITES (Pflug, 1952),} Delcourt and Sprumont, 1955

30. Concavisporites sp. (Plate 4, Fig. 5). 


\section{Genus FOVEOSPORITES}

31. Foveosporites canalis Balme, 1957 (Plate 4, Fig. 3). Mid-Cretaceous of Australia (Playford et al., 1975).

Infraturma MURORNATI R. Potonié and Kremp, 1954

Genus LYCOPODIUMSPORITES Thiergart ex Delcourt and Sprumont, 1955

32. Lycopodiumsporites cf. eminulus Dettmann, 1963 (Plate 4, Figs. 6-7). Eocene of Argentina (Archangelsky, 1972).

33. Lycopodiumsporites rosewoodensis (de Jersey) (Plate 4, Fig. 10). Lower Cretaceous of Australia (Burger, 1974).

34. Lycopodiumsporites sp. (Plate 4, Figs. 8-9).

\section{Genus KL UKISPORITES Couper, 1958}

35. Klukisporites pseudoreticulatus Couper, 1958 (Plate 4, Fig. 11). Cretaceous sediments of England (Playford, 1971).

Genus CICATRICOSISPORITES Potonié and Gelletich, 1933

36. Cicatricosisporites australiensis (Cookson), Potonié, 1956 (Plate 4, Fig. 12). Neocomian?-Cenomanian of Australia (Hill et al., 1968); Cretaceous sediments of Australia (Dettmann and Playford, 1969), and England (Playford, 1971); Neocomian of Australia (Burger, 1973, 1974).

37. Cicatricosisporites sp. (Plate 4, Fig. 13).

\section{Infraturma TRICRASSATI Dettmann, 1963 \\ Genus GLEICHENIIDITES (Ross ex Delcourt and Sprumont), Dettmann, 1963}

38. Gleicheniidites senonicus Ross, 1949 (Plate 5, Figs. 1-2). Eocene of Argentina (Archangelsky, 1972); Cretaceous deposits of the eastern to north Atlantic Ocean (Kotova, 1978).

39. Gleicheniidites circinidites (Cookson), Burger, 1976 (Plate 5, Fig. 5). Cenomanian of Australia (Burger, 1976).

40. Gleicheniidites cf. G. trijugatus (Pierce), Burger, 1976 (Plate 5, Figs. 3-4). Cenomanian of Australia (Burger, 1976).

Genus CLAVIFERA Bolkhovitina, 1966

41. Clavifera triplex (Bolkhovitina), Bolkhovitina, 1966 (Plate 5, Fig. 13). Cretaceous of Australia (Dettmann and Playford, 1969); Paleocene of Argentina (Archangelsky, 1973); Cenomanian of Australia (Burger, 1976).

\section{Genus NEORAISTRICKIA Potonié}

42. Neoraistrickia sp. (Plate 5, Fig. 8). Paleocene of Argentina (Archangelsky, 1973).

Infraturma AURICULATI Schopf, emend. Dettmann, 1963 Genus TRILOBOSPORITES Pant ex Potonié, 1956

43. Trilobosporites purverulentus (Verbitskaya), Dettmann, 1963 (Plate 5, Fig. 6). Lower Cretaceous of Canada (Playford, 1971). 44. Trilobosporites sp.? (Plate 5, Fig. 7).

\section{Genus TRILITES Erdtman ex Couper, emend. Dettmann, 1963}

45. Trilites cf. paravallatus W. Kr., 1959 (Plate 5, Figs. 9-10). Paleogene of Hungary (Kedves, 1973).

46. cf. Trilites sp. 1 (Plate 5, Figs. 11-12).

47. cf. Trilites sp. 2 (Plate 6, Figs, 1-2).

\section{Genus DICKSONIA L'Haritier}

48. Dicksonia aff. squarrosa Swartz (Plate 6, Figs. 3-4). Maestrichtian to present-day New Zealand (Couper, 1960); bottom sediments in the western part of the Pacific Ocean (Koreneva, 1964). 49. Dicksonia sp. (Plate 6, Figs. 5-6).

\section{Infraturma CINGULATI R. Potonié and Klaus,} emend. Dettmann, 1963

\section{Genus FORAMINISPORIS Krutzsch, 1959}

50. Foraminisporis dailyi (Cookson and Dettmann), Dettmann, 1963 (Plate 6, Fig. 7). Cretaceous sediments of Australia (Hill et al., 1968) and Canada (Playford, 1971).

51. Foraminisporis sp. (Plate 6, Fig. 9).

52. Foraminisporis wonthaggiensis (Cookson and Dettmann), Dettmann, 1963 (Plate 6, Fig. 8). Aptian-Albian of Australia (Dettmann, 1963); Cretaceous sediments of Australia (Hill et al., 1968); Mid-Cretaceous of North America (Norris, 1967; Singh, 1971); Cenomanian of Australia (Burger, 1976).

\section{Genus CYATHEACIDITES (Cookson), Potonié, 1956}

53. Cyatheacidites sp. 1 (Plate 7, Figs. 1-2).

54. Cyatheacidites sp. 2 (Plate 7, Figs. 3-4).

\section{Genus CINGUTRILETES Pierce, emend. Dettmann, 1963}

55. Cingutriletes australis (Cookson) Archangelsky, 1972 (Plate 7, Fig. 5). Eocene of Argentina (Archangelsky, 1972).

56. Cingutriletes clavus (Balme), Dettmann, 1963 (Plate 7, Fig. 6). Lower Cretaceous of Australia (Burger, 1974) and Canada (Vag. volgyi and Hills, 1969).

\section{Infraturma SCULPTATOMONOLETI}

Genus POLYPODIIDITES Ross, 1949, emend. Potonié, 1966

57. Polypodiidites speciosus (Harris), Archangelsky, 1972 (Plate 7, Fig. 9). Eocene of Argentina (Archangelsky, 1972).

58. Polypodiidites sp. (Plate 7, Figs. 7-8).

Turma HILATES Dettmann, 1963 Genus AEQUITRIRADITES

59. Aequitriradites sp. (Plate 8, Fig. 8).

\section{Incertae sedis}

60. Triletes sp. E; Koreneva, 1964 (Plate 8, Fig. 1). Bottom sediments in the western part of the Pacific Ocean (Koreneva, 1964). 61. Form sp. 1 (Plate 8, Figs. 2-3).

62. Form sp. 2 (Plate 8, Figs. 4-5).

63. Form sp. 3 (Plate 8, Fig. 6).

64. Form sp. 4 (Plate 8, Fig. 7).

\section{Anteturma POLLENITES Potonié, 1931 Infraturma SACCIZONATI Bhardwaj, 1957 \\ Genus TSUGAEPOLLENITES Potonié and Venitz, emend. Potonié, 1958}

65. Tsugaepollenites sp. (Plate 9, Fig. 1).

\section{Subturma DISACCITES Cookson, 1947 \\ Genus PINUSPOLLENITES Raatz, 1937}

66. Pinuspollenites sp. (Plate 9, Fig. 2).

\section{Genus PODOCARPIDITES Cookson ex Couper, 1953}

67. Podocarpidites marwickii Couper, 1953 (Plate 9, Fig. 3). Lower Cretaceous to lower Oligocene of New Zealand (Couper, 1953); Albian to upper Eocene of New Zealand (Couper, 1960); Maestrichtian-Paleocene of Argentina (Freile, 1972); Upper Cretaceous-Paleocene of Patagonia (Archangelsky and Romero, 1974a); Eocene of Argentina (Romero, 1977).

68. Podocarpidites elegans Romero, 1977 (Plate 9, Figs. 4-5). Eocene of Argentina (Romero, 1977); Upper Cretaceous-Paleocene of Patagonia (Archangelsky and Romero, 1974a).

69. Podocarpidites microreticuloidata Cookson, 1947 (Plate 9, Fig. 6). Upper Cretaceous-Paleocene of Patagonia (Archangelsky and Romero, 1974a); Eocene of Argentina (Romero, 1977).

70. Podocarpidites sp. (Plate 9, Fig. 11). 


\section{Genus DACR YDIUMITES (Cookson and Pike),} Harris, 1965

71. Dacrydiumites sp. (Plate 9, Fig. 7).

\section{Genus DACRYDIUM Soland.}

72. Dacrydium cupressinum Soland. ex Forst. (Plate 9, Figs. 8-9). Lower Oligocene to Recent of New Zealand (Couper, 1953); bottom sediments in the western part of the Pacific Ocean (Koreneva, 1964); Maestrichtian-Paleocene-Eocene of Patagonia (Archangelsky and Romero, 1974a, b); Upper Cretaceous-Paleogene of Argentina (Romero, 1977).

73. Dacrydium aff. cupressinum Soland. ex Forst. (Plate 9, Fig. 10). Maestrichtian to present-day New Zealand (Couper, 1960); bottom sediments in the western Pacific Ocean (Koreneva, 1964).

\section{Genus PHYLLOCLADIDITES Cookson, 1947}

74. Phyllocladidites mawsonii Cookson, 1947 (Plate 10, Fig. 1). Lower Cretaceous-lower Oligocene of New Zealand (Couper, 1953); Cretaceous-Tertiary of Patagonia (Archangelsky and Romero, 1974a, b); Lower Cretaceous-Pliocene of Argentina (Romero, 1977).

75. Phyllocladidites mawsonii f. verrucosus Cookson, 1947 (Plate 10, Fig. 2). Paleocene-Eocene of Argentina (Romero, 1977).

76. Phyllocladidites sp. (Plate 10, Figs. 3-4).

\section{Genus MICROCACHRYDITES Cookson, 1947}

77. Microcachrydites antarcticus Cookson, 1947 (Plate 10, Figs. 5-6). Lower Cretaceous to lower Oligocene of New Zealand (Couper, 1953); Mesozoic and Cenozoic sediments of New Zealand (Couper, 1960); Bajocian-Tertiary of Australia (Balme, 1964; Hill et al., 1968); Cretaceous sediments of Australia (Dettmann and Playford, 1969); Paleocene-Eocene of Patagonia (Archangelsky and Romero, 1974a, b); Eocene of Argentina (Romero, 1977).

78. Microcachrydites parvus Couper, 1960 (Plate 10, Fig. 7). Upper Oligocene-lower Pleistocene of New Zealand (Couper, 1960).

\section{Genus TRISACCITES (Cookson), Menendez, 1968}

79. Trisaccites microsaccatus (Couper) Couper, 1960 (Plate 10, Fig. 8). Maestrichtian-Paleocene-Eocene of Patagonia (Archangelsky and Romero, 1974a, b).

80. Trisaccites sp. (Plate 10, Fig. 9).

\section{Subturma AZONALETES Luber, emend.}

R. Potonié and Kremp, 1954

Genus ARAUCARIACITES Cookson, 1947

81. Araucariacites sp. (Plate 10, Fig. 10).

Subturma POLYPLICATUS Erdtman, 1952

Genus EPHEDRA L.

82. Ephedra sp. (Plate 10, Figs. 11-12).

Subturma MONOCOLPATES Iversen and Troels-Smith, 1950

Genus MONOSULCITES Cookson ex Couper, 1958

83. Monosulcites sp. (Plate 10, Fig. 13).

\section{Genus LILIACIDITES Couper, 1953}

84. Liliacidites $\mathrm{sp}$.

\section{Subturma TRIPTYCHES Naumova, 1939,} emend. R. Potonié, 1960

Genus TRICOLPITES Cookson ex Couper, 1958, emend. R. Potonié, 1960

85. "Tricolpites" cf. gillii Cookson, 1957 (Plate 10, Figs. 14-15). Paleocene of Argentina (Archangelsky, 1973).

86. Tricolpites alveolatus Couper, 1953 (Plate 10, Fig. 16). Lower Eocene to Miocene of New Zealand (Couper, 1953).
87. Tricolpites brevicolpus Couper, 1960 (Plate 11, Figs. 1-2). Maestrichtian of New Zealand (Couper, 1960).

88. Tricolpites cf. brevicolpus Couper, 1960 (Plate 11, Figs. 3-4).

89. Tricolpites fissilis Couper, 1960 (Plate 11, Fig. 5). Upper Senonian of New Zealand (Couper, 1960).

90. Tricolpites waiparaensis Couper, 1960 (Plate 11, Figs. 6-8). Upper Cretaceous of New Zealand (Couper, 1960).

91. Tricolpites sp. 1 (Plate 11, Figs. 9-10).

92. Tricolpites sp. 2 (Plate 11, Figs. 11-12).

93. Tricolpites sp. 3 (Plate 11, Figs. 13-16).

94. Tricolpites sp. 4 (Plate 11, Fig. 17).

95. Tricolpites sp. 5 (Plate 11, Figs. 18-19).

\section{Genus TRICOLPOROPOLLENITES Thomson and Pflug, 1953}

96. Tricolporopollenites sp. 1 (Plate 12, Fig. 1).

97. Tricolporopollenites sp. 2 (Plate 12, Fig. 2).

98. Tricolporopollenites sp. 3 (Plate 12, Figs. 3-4).

99. Tricolporopollenites sp. 4 (Plate 12, Fig. 5).

\section{Genus TRICOLPORITES}

100. Tricolporites scabratus Harris, 1965 (Plate 12, Figs. 6-8). Paleocene-Eocene of Australia (Harris, 1965).

Genus PSILATRICOLPORITES (van der Hammen), Pierce, 1961

101. Psilatricolporites sp. (Plate 12, Figs. 9-10).

\section{Genus RHOIPITES Wodehouse, 1933}

102. Rhoipites communis Sah, 1967 (Plate 12, Figs. 11-12) Upper Neogene of Burundi (Sah, 1967).

103. Rhoipites baculatus Archangelsky, 1973 (Plate 12, Figs. 13-14). Paleocene of Argentina (Archangelsky, 1973).

104. Rhoipites striatoreticulatus Sah, 1967 (Plate 12, Figs. 15-16). Upper Neogene of Burundi (Sah, 1967).

105. Rhoipites sp. (Plate 12, Figs. 17-18).

\section{Genus SENIPITES Srivastava}

106. Senipites cf. tercrassata Archangelsky, 1973 (Plate 12, Figs. 19-21). Paleocene of Argentina (Archangelsky, 1973).

\section{Genus TETRACOLPORITES Couper, 1953}

107. Tetracolporites sp. (Plate 12, Figs. 22-23).

Turma POROSES Naumova, emend. R. Potonié, 1960 Subturma TRIPORINES Naumova, emend. R. Potonié, 1960 Genus TRIORITES Cookson ex Couper

108. Triorites harrisii Couper, 1953 (Plate 13, Figs. 1-2). Danian to upper Pliocene of New Zealand (Couper, 1960).

\section{Genus CASUARINIDITES Cookson}

109. Casuarinidites cainozoicus Denmark (Plate 13, Figs. 3-4). Eocene-Oligocene of Australia (Cookson, 1964).

110. Casuarinidites sp. (Plate 13, Figs. 5-7).

\section{Genus PROTEACIDITES Cookson ex Couper 1954}

111. Proteacidites minimus Couper, 1954 (Plate 13, Figs. 8-9). Upper Oligocene to lower Pleistocene of New Zealand (Couper, 1960).

112. Proteacidites cf. retiformis Couper, 1960 (Plate 13, Figs. 10-11). Upper Senonian of New Zealand (Couper, 1960).

113. Proteacidites rectomarginis Cookson, 1950 (Plate 13, Figs. 1415). Tertiary sediments of Australia (Cookson, 1950); middle Eocene of New Zealand (Couper, 1960).

114. Proteacidites sp. (Plate 13, Figs. 12-13).

\section{Genus MYRTACEIDITES Cookson and Pike, 1954,} ex R. Potonié, 1960

115. Myrtaceidites sp. (Plate 13, Figs. 16-17).

116. Myrtaceidites parvus forma nesus Cookson and Pike, 1954 (Plate 13, Figs. 18-20). Eocene to Pliocene of Australia (Cookson and Pike, 1954); Eocene of Chile (Takahashi, 1977). 


\section{Genus NOTHOFAGIDITES R. Potonié, 1960} Type Menziesii

117. Nothofagidites asperus (Cookson), Romero, 1973 (Plate 14, Figs. 1-2). Paleocene, Eocene, Oligocene of Argentina (Menendez and Caccavari de Filice, 1975); Eocene of Argentina (Romero, 1977).

\section{Type Brassi}

118. Nothofagidites deminuta (Cookson), Romero, 1977 (Plate 14, Figs. 3-4). Eocene-Miocene of Australia (Cookson, 1958); Paleogene of Patagonia (Archangelsky and Romero, 1974a, b); Eocene of Argentina (Romero, 1977).

119. Nothofagidites cranwellae (Couper), Fasola, 1969 (Plate 14, Fig. 5). Middle Oligocene-upper Pliocene of New Zealand (Couper, 1960); Paleogene of Argentina (Mendendez and Caccavari de Filice, 1975); Eocene-Oligocene of Patagonia (Archangelsky and Romero, 1974b); Eocene of Argentina (Romero, 1977).

120. Nothofagidites spinosus Couper, 1960 (Plate 14, Figs. 6-8). Upper Oligocene-middle Miocene (Couper, 1960).

121. Nothofagidites sp. 1 (Plate 14, Fig. 11).

\section{Type Fusca}

122. Nothofagidites brachispinulosa (Cookson), Harris, 1965 (Plate 14, Figs. 9-10). Eocene-Miocene of Australia (Cookson, 1958); Eocene-Oligocene of Patagonia (Archangelsky and Romero, 1974b); Eocene of Argentina (Romero, 1977).

123. Nothofagidites cincta (Cookson), Fasola, 1969 (Plate 14, Figs. 15-16). Eocene-Miocene of Australia (Cookson, 1958); EoceneOligocene of Patagonia (Archangelsky and Romero, 1974); Eocene of Argentina (Romero, 1977).

124. Nothofagidites sp. 2 (Plate 14, Figs. 12-14).

125. Nothofagidites sp. 3 (Plate 14, Figs. 17-19).

126. Nothofagidites sp. 4 (Plate 14, Figs. 20-21).

\section{Genus PARSONSIDITES Couper, 1960}

127. Parsonsidites cf. psilatus Couper, 1960 (Plate 15, Figs. 1-5). Tertiary sediments of New Zealand (Couper, 1960).

128. Parsonsidites $\mathrm{cf}$. conspicuus Frederiksen, 1973 (Plate 15, Figs. 6-7). Middle, upper Eocene-lower Oligocene of Mississippi and Alabama (Frederiksen, 1973).

\section{Genus $I L E X \mathbf{L}$}

129. Ilex sp. (Plate 15, Fig. 13).

\section{Genus RHIZOPHORA L.}

130. Rhizophora sp. 1 (Plate 15 , Figs. 8-9).

131. Rhizophora sp. 2 (Plate 15, Figs. 10-11).

Genus ALNUS L.

132. Alnus sp. (Plate 15, Fig. 12).

\section{Genus POLYGONUM L.}

133. Polygonum sp. (Plate 15, Figs. 17-18).

134. Chenopodiaceae (Plate 15, Figs. 14-16).

\section{Incertae sedis}

135. Form sp. 1 (Plate 16, Figs. 1-3).

136. Form sp. 2 (Plate 16, Figs. 4-5).

137. Form sp. 3 (Plate 16, Fig. 6).

138. Form sp. 4 (Plate 16, Figs. 7-8).

139. Form sp. 5 (Plate 16, Fig. 9).

\section{ACKNOWLEDGMENTS}

The author is grateful to Professor V. A. Vakhrameev and Dr. R. E. Giterman for critical comments concerning the paper, and thanks N. P. Zvezdina for maceration of the samples and A. I. Nazarov for microphotographs.

\section{REFERENCES}

Archangelsky, S., 1972. Esporas de la Formación Río Turbio (Eoceno), Provincia de Santa Cruz. Paleontológia, 6(No. 39):65-100. 1973a. Palinológia del Paleoceno de Chubut. I. Descripciónes sistemáticas. Ameghiniana, 10(No. 4):339-399.

1973b. Paleocene and Eocene pollen assemblages from Patagonia, Argentina. The Palynology of Cenophytic: Proceedings of III International Palynological Conference: Moscow, pp. 96-100.

Archangelsky, S., and Romero, E. J., 1974a. Polen de Gimnospermas (Coniferas) del Cretácico Superior y Paleoceno de Patagonia. Ameghiniana, 11(No. 3):217-236.

1974b. Los registros más antiguos del polen de Nothofagus (Fagaceae) de Patagonia (Argentina y Chile). Bol. Soc. Bot. Mex., 3:13-30.

Balme, B. E., 1957. Spores and Pollen Grains from the Mesozoic of Western Australia. CSIRO Div. Coal Res. Ref. T.C. 25.

1964. The palynological record of Australian pre-Tertiary floras. In Cranwell, L. M. (Ed.), Ancient Pacific Floras: The Pollen Story: Honolulu (University of Hawaii Press), pp. 49-80.

Bolkhovitina, N. A., 1966. The fossil spores of the ferns of the family Gleicheniaceae (taxonomy and distribution). The Importance of Palynological Analysis for Stratigraphic and Palaeofloristic Investigations: Moscow (Nauka), pp. 65-75.

Burger, D., 1973. Spore zonation and sedimentary history of the Neocomian, Great Artesian Basin, Queensland. Spec. Publ. Geol. Soc. Aust., 4:87-118.

1974. Palynology of the subsurface Lower Cretaceous strata in the Surat Basin, Queensland. Bull. Bur. Miner. Resour. Geol. Geophys. Aust., 150:27-42.

1976. Cenomanian spores and pollen grains from Bathurst Island, Northern Territory, Australia. Bull. Bur. Miner. Resour. Geol, Geophys. Aust., 151:114-166.

Campbell, D. H., 1948. An Outline of Plant Geography: Moscow.

Cookson, J. C., 1947. Plant microfossils from the lignites of the Kerguelen Archipelago. Repts. B.A.N.Z. Antarctic Res. Exped. (192931) Ser., A 2(8):129-42. 1950. Fossil pollen grains of proteaceous type from Tertiary deposits in Australia. Aust. J. Scient. Res., Ser. B, 3:166-177. 1957. On some Australian Tertiary spores and pollen grain that extend the geological and geographical distribution of living genera. Proc. Roy. Soc. Vict., 69:41-53.

1958. Fossil pollen grains of Nothofagus from Australia. Proc. R. Soc. Victoria, 71:25-30.

), 1964. Some early angiosperms from Australia: The pollen record. In Cranwell, L. M. (Ed.), Ancient Pacific Floras: The Pollen Story: Honolulu (University of Hawaii Press), pp. 81-84.

Cookson, J. C., and Pike, R. M., 1954. Some dicotyledonous pollen type from Cainozoic deposits in the Australian region. Aust. J. Bot., 2(no. 2):197-219.

Couper, R. A., 1953. Upper Mesozoic and Cainozoic Spores and Pollen Grains from New Zealand. New Zealand Geol. Surv. Paleontol. Bull., 22.

Couper, R. A., 1958. British Mesozoic microspores and pollen grains: A systematic and stratigraphic study. Palaeontolographica, $B, 103$ : 75-179.

1960. New Zealand Mesozoic and Cainozoic Plant Microfossils. New Zealand Geol. Surv. Paleontol. Bull., 32.

Cranwell, L. M., 1964. Antarctica: Cradle or grave for its Nothofagus? In Cranwell, L. M. (Ed.), Ancient Pacific Floras: The Pollen Story: Honolulu (University of Hawaii Press), pp. 87-93.

Delcourt, A., Dettmann, M. E., and Hughes, N. F., 1963. Revision of some Lower Cretaceous microspores from Belgium. Palaeontology, 6(2):282-292.

Delcourt, A., and Sprumont, G., 1955. Les Spores et Grains de Pollen du Wealdien du Hainaut. Mem. Soc. Belg. Geol. N.S.4, 5.

Dettmann, M. E., 1963. Upper Mesozoic microfloras from Southeastern Australia. Proc. R. Soc. Victoria, 77(1):1-148.

Dettmann, M. E., and Playford, G., 1969. Palynology of the Australian Cretaceous: A review. In Campbell, K. S. W. (Ed.), Stratigraphy and Paleontology: Essays in Honour of Dorothy Hill: Canberra (ANU Press), pp. 174-210.

Fasola, A., 1969. Estudio palinologico de la Formacion Loreto (Terciario Medio), Provincia de Magallanes, Chile. Ameghiniana, 6(No. 1):3-19.

Frederiksen, N. O., 1973. New mid-Tertiary spores and pollen grains from Mississippi and Alabama. Tulane Stud. Geol. Paleontol., 10(No. 2):65-85. 
Freile, C., 1972. Estudio palinológico de la Formacion Cerro Dorotea (Maestrichtiano-Paleoceno) de la Provincia de Santa Cruz I. Paleontologia, 6(No. 38):39-63.

Harris, W. K., 1965. Basal Tertiary microfloras from the Princetown Area, Victoria, Australia. Paleontographica, B, 115:75-106.

Hill, D., Playford, G., and Woods, J. T., 1968. Cretaceous Fossils of Queensland. Queensl. Palaeontogr. Soc.

Kedves, M., 1973. Paleogene Fossil Sporomorphs of the Bakony Mountains. Pt. 1. Stud. Biol. Acad. Sci. Hungaricae, 12.

Kemp, E. M., 1975. Palynology of Leg 28 Drill Sites, Deep Sea Drilling Project. In Hayes, D. E., Frakes, L. A., et al., Init. Repts. DSDP, 28: Washington (U.S. Govt. Printing Office), 599-623.

Koreneva, E. V., 1964. Pollen and spores in bottom sediments of the western Pacific. Tr. Inst. Geol. Nauk U.S.S.R., Geol. Ser., 109: $1-88$.

Kotova, I. Z., 1978. Spores and pollen from Cretaceous deposits of the Eastern North Atlantic Ocean, Deep Sea Drilling Project, Leg 41, Sites 367 and 370. In Lancelot, Y., Seibold, E., et al., Init. Repts. DSDP, Suppl. to Vols. 38, 39, 40, and 41: Washington (U.S. Govt. Printing Office), 841-881.

Krutzsch, W., 1959. Mikropaläontologische (sporenpaläontologische) Untersuchungen in der Braunkohle des Geiseltales. Geologie, Beih. Nos. 21-22.

Menendez, C. A., 1968. Estudio palinológico del Jurásico Medio de Picun Lentu, Neuquén. Ameghiniana, 5(No. 10):379-405.

Menendez, C. A., and Caccavari de Filice, M. A., 1975. Las especies de Nothofagidites (polen fósil de Nothofagus) de sedimentos Terciarios y Cretácicos de Estancia La Sara, Norte de Tierra del Fuego, Argentina. Ameghiniana, 12(No. 2):165-183.

Norris, G., 1967. Spores and pollen from the Lower Colorado Group (Albian-Cenomanian) of Central Alberta. Palaeontographica, B, 120(1-4):72-115.

Pflug, H. D., 1953. Zur Entstehung und Entwicklung des Angiospermiden-Pollen in der Erdgeschichte. Palaeontographica, $B, 95(4 / 6)$ : 60-171.

Pierce, R. L., 1961. Lower Upper Cretaceous Plant Microfossils from Minnesota. Bull. Minn. Geol. Surv., 42.

Playford, G., Haig, D. W., and Dettmann, M. E., 1975. A mid-Cretaceous microfossil assemblage from the Great Artesian Basin, northwestern Queensland. Neues Jahrb. Geol. Palaont. Abh., 149(No. 3):333-362.
Pocock, S. A. J., 1964. Pollen and spores of Chlamydospermidae and Schizaeaceae from Upper Mannville strata of the Saskatoon area of Saskatchewan. Grana Palynologica, 5(No. 2):129-209.

Potonié, R., 1956. Synopsis der Gattungen der Sporae dispersae. I Teil: Sporites. Beih. Geol. Jahrb., 23. 1958. Synopsis der Gattungen der Sporae dispersae. II Teil: Sporites (Nachträge Saccites, Aletes, Praecolpates, Poliplicates, Monocolpates). Beih. Geol. Jahr., 31:1-114. 1960. Synopsis der Gattungen der Sporae dispersae. III Teil: Nachtrage Sporites. Fortsetzung Pollenits. Beih. Geol. Jahrb., 39.

Potonié, R., and Kremp, G., 1954. Die Gattungen der palaozoischen Sporae dispersae und ihren Stratigraphie. Geol. Jahrb., 69: 111-194.

Raatz, G. V., 1937. Mikrobotanisch-stratigraphische Untersuchung der Braunkohle des Muskauer Bogens. Abh. Preuss. geol. Landesanst. N.F., 183:1-48.

Romero, E. J., 1977. Polen de Gimnospermas y Fagaceas de la Formacion Rio Turbio (Eoceno), Santa Cruz, Argentina: Unidad de paleobotanica y palinológica: Buenos Aires (Centro de Investigaciones en Recursos Geologicos).

Ross, N. E., 1949. On a Cretaceous pollen and spore bearing clay of Scania: Bull. Geol. Inst. Uppsala, 34:25-43.

Sah, S. C. D., 1967. Palynology of an Upper Neogene Profile from Rusizi Valley (Burundi). Ann. Mus. R. Afr. Cent. Tervuren, Belg., Ser. IX in $8^{\circ}$, Sci. Geol, no. 57.

Singh, C., 1971. Lower Cretaceous microfloras of the Peace River area, Northwestern Alberta. Ibid, 28, p. 542.

Stover, L. E., 1964. Comparison of three Cretaceous spore-pollen assemblages from Maryland and England. In Cross, A. T. (Ed.), Palynology in Oil Exploration. Society of Economic Paleontologists and Mineralogists, Special Publication 11:143-152.

Takahashi, K., 1977. Palynology of the Lower Tertiary Concepcion Formation, Central Chile. Trans. Proc. Palaeontol. Soc. Japan, NS, No. 106 , pp. 71-88.

Thomson, P. W., and Pflug, H., 1953. Pollen und Sporen des mitteleuropäischen Tertiärs: Gesamtubersicht über die stratigrafisch und paläontologish wichtigen Formen. Palaeontographica B, 94:1-138.

Vagvolgyi, A., and Hills, L. V., 1969. Microflora of the Lower Cretaceous McMurray Formation, Northeast Alberta. Bull. Can. Pet. Geol., 17(No. 2):155-181.

Wodehouse, R. P., 1933. Pollen Grains: New York (McGraw-Hill). 


\section{G. M. BRATZEVA}
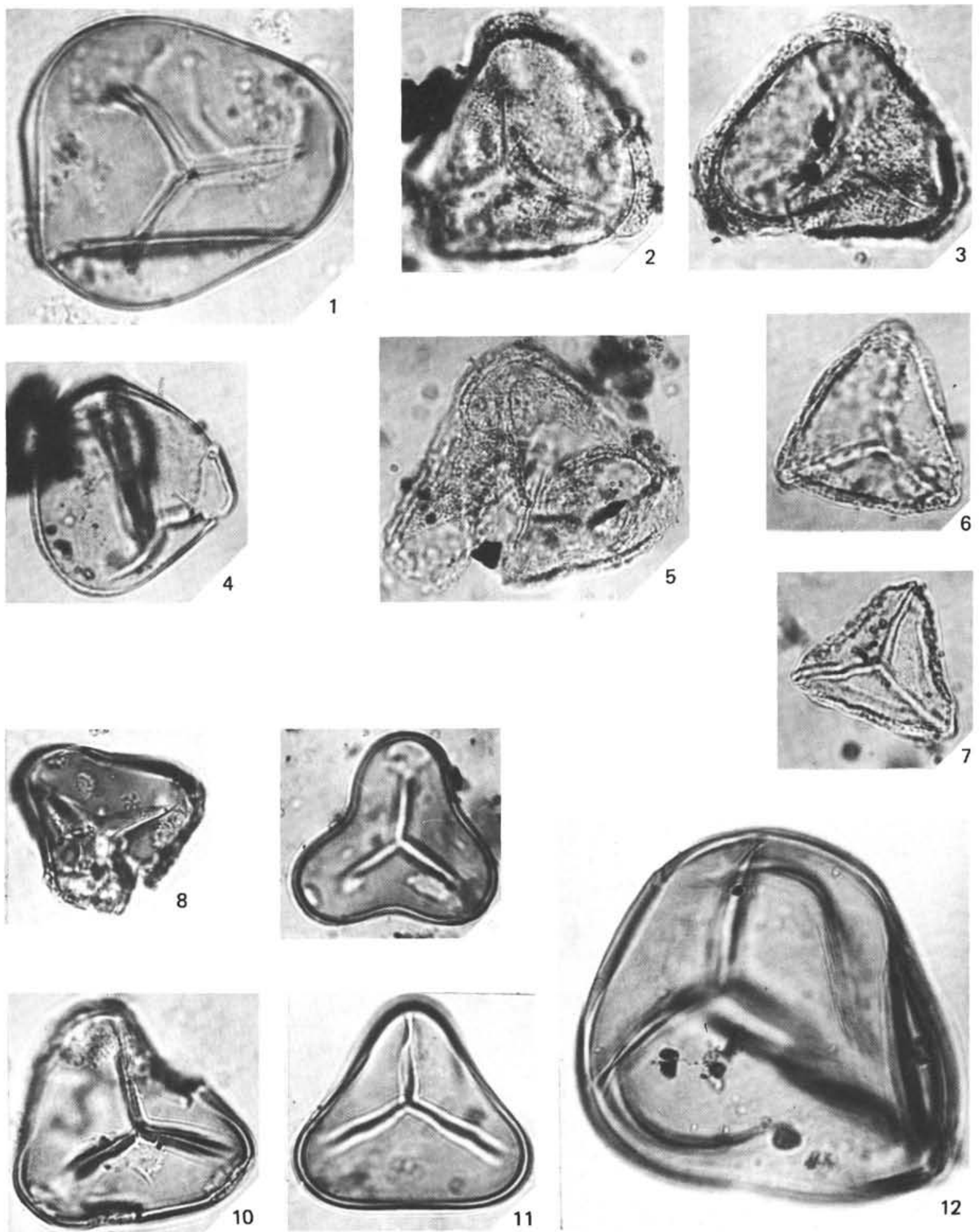

Plate 1. (All specimens magnified $\times 1000$.) 1. Leiotriletes microadriennis Krutzsch, 1959, Sample 511-18-1, 34-36 cm. 2-3. Lygodiidites cf. balmei Pocock, 1964 (2) Sample 511-6-2, 40-42 cm. (3) Sample 511-9-3, 96-92 cm. 4. Leiotriletes sp., Sample 511-5-2, 20-22 cm. 5. Lygodiidites sp., Sample 511-11-3, 40-44 cm. 6-7. cf. Lygodium? labratum Frederiksen, 1973 (6) Sample 511-6-2, 40-42 cm (7) Sample 511-5-2, 20-22 cm. 8-11. Cyathidites minor Couper, 1953 (8) Sample 511-9-3, 92-96 cm (9) Sample 511-5-4, 20-22 cm (10) Sample 511-12-1, 25-27 cm (11) Sample 511-6-1, 40-42 cm. 12. Cyathidites australis Couper, 1953, Sample 511-12-1, 25-27 cm. 

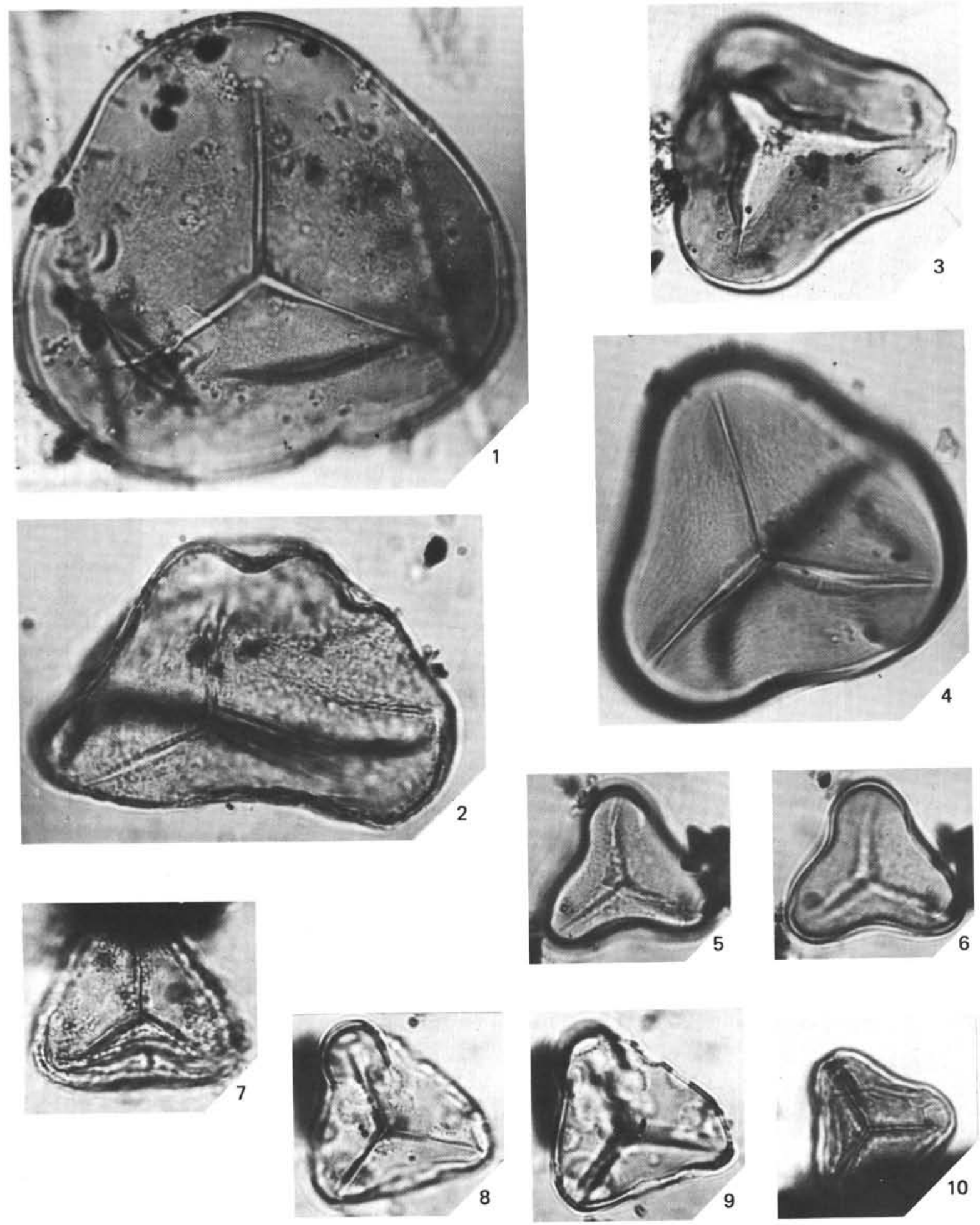

Plate 2. (All specimens magnified $\times 1000$.) 1. Cyathidites patagonicus Archangelsky, 1972, Sample 511-16-2, 33-35 cm. 2. Cyathidites punctatus (Delcourt and Sprumont), Delcourt et al., 1963, Sample 511-5-2, 20-22 cm. 3. Cyathidites sp. 1, Sample 511-12-1, 25-27 cm. 4. Cyathidites sp. 2, Sample 511-9-7, 42-46 cm. 5-6. Cyathidites sp. 3, Sample 511-9-7, 42-46 cm. 7. Cyathidites sp. 4, Sample 511-12-1, 25-27 cm. 8-9. Deltoidospora cf. delicata Sah, 1967, Sample 511-5-2, 20-22 cm. 10. Deltoidospora sp., Sample 511-12-1, 25-27 cm. 

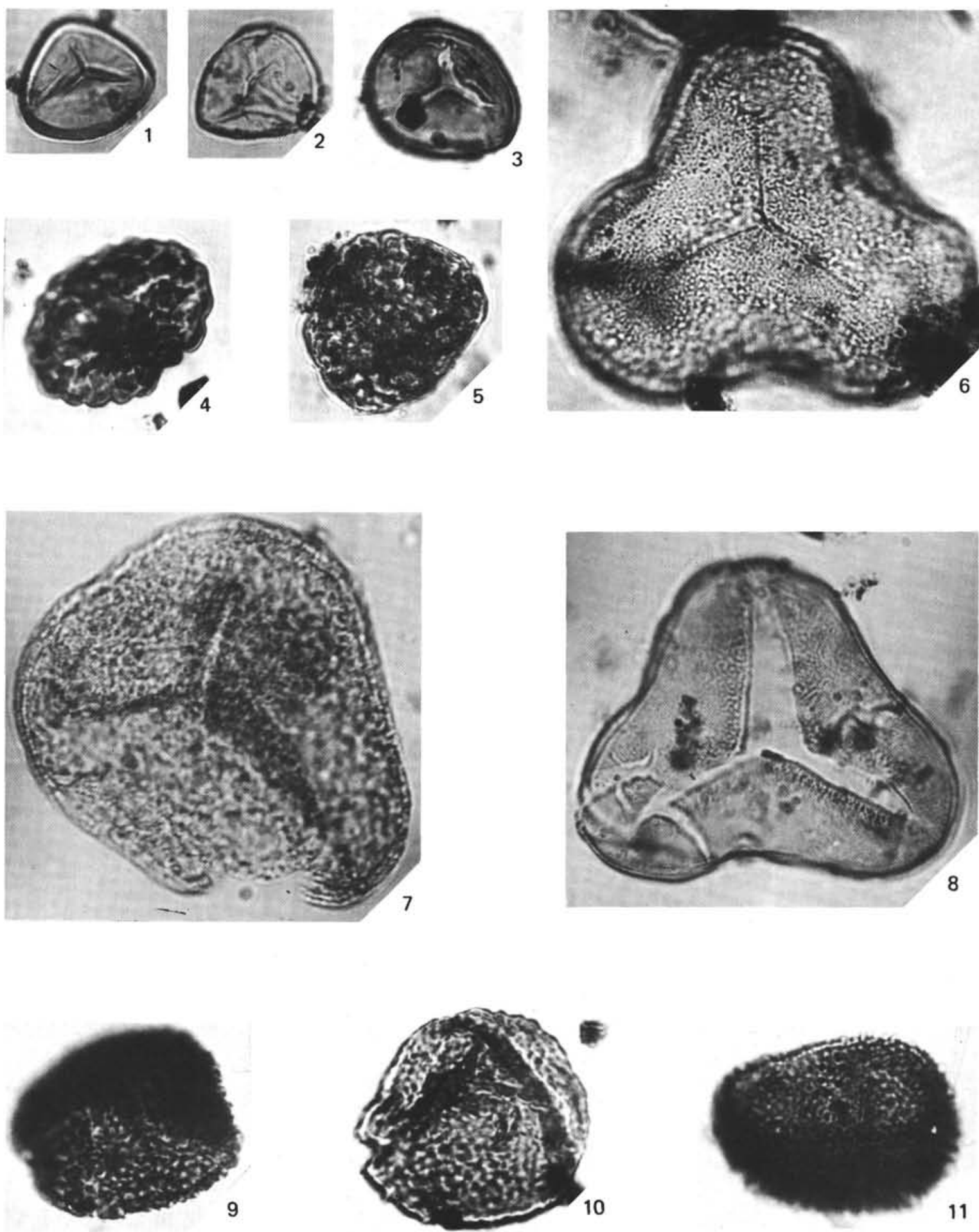

Plate 3. (All specimens magnified $\times 1000$.) 1. Stereisporites antiquasporites (Wilson and Webster), Dettmann, 1963, Sample 511-11-3, 40-44 cm. 2. Stereisporites concepcionensis Takahashi, 1977, Sample 511-5-2, 20-22 cm. 3. Stereisporites sp., Sample 511-6-2, 40-42 cm. 4. Leptolepidites verrucatus Couper, 1953, Sample 511-9-7, 42-46 cm. 5. Leptolepidites sp., Sample 511-11-3, 40-44 cm. 6. Concavissimisporites punctatus (Delcourt and Sprumont), Pocock, 1964, Sample 511-6-2, 40-42 cm. 7. Concavissimisporites granulatus Pocock, 1964, Sample 5119-7, 42-46 cm. 8. Concavissimisporites sp., Sample 511-9-7, 42-46 cm. 9. Baculatisporites sp.?, Sample 511-12-1, 25-27 cm. 10. Osmundacidites wellmanii Couper, 1953, Sample 511-12-1, 25-27 cm. 11. Osmundacidites sp., Sample 511-9-2, 92-96 cm. 

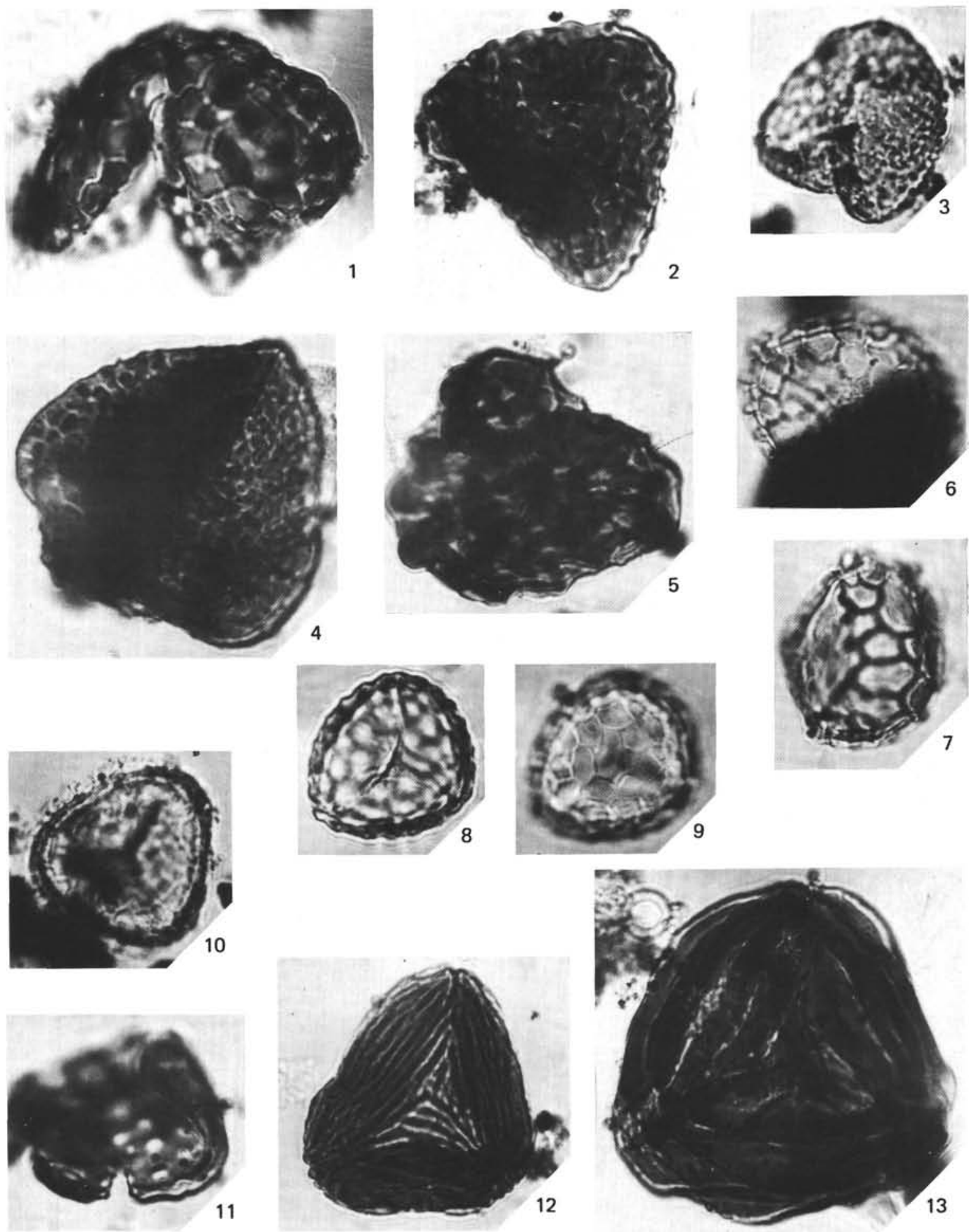

Plate 4. (All specimens magnified $\times 1000$.) 1. Verrucatosporites transdanubicus Kedves, 1973, Sample 511-5-1, 20-22 cm. 2. Verrucatosporites sp. 1, Sample 511-9-4, 92-96 cm. 3. Foveosporites canalis Balme, 1957, Sample 511-5-2, 20-22 cm. 4. cf. Verrucatosporites sp. 2, Sample $511-9-7,42-46 \mathrm{~cm}$. 5. Concavisporites sp., Sample 511-9-7, 42-46 cm. 6-7. Lycopodiumsporites cf. eminulus Dettmann, 1963 (6) Sample 511-12-1, 25-27 cm, (7) Sample 511-11-3, 40-44 cm. 8-9. Lycopodiumsporites sp., Sample 511-12-1, 25-27 cm. 10. Lycopodiumsporites rosewoodensis (de Jersey), Sample 511-12-1, 25-27 cm. 11. Klukisporites pseudoreticulatus Couper, 1958, Sample 511-9-4, 92-96 cm. 12. Cicatricosisporites australiensis (Cookson), Potonié, 1956, Sample 511-5-2, 20-22 cm. 13. Cicatricosisporites sp., Sample 511-12-1, 25-27 cm. 

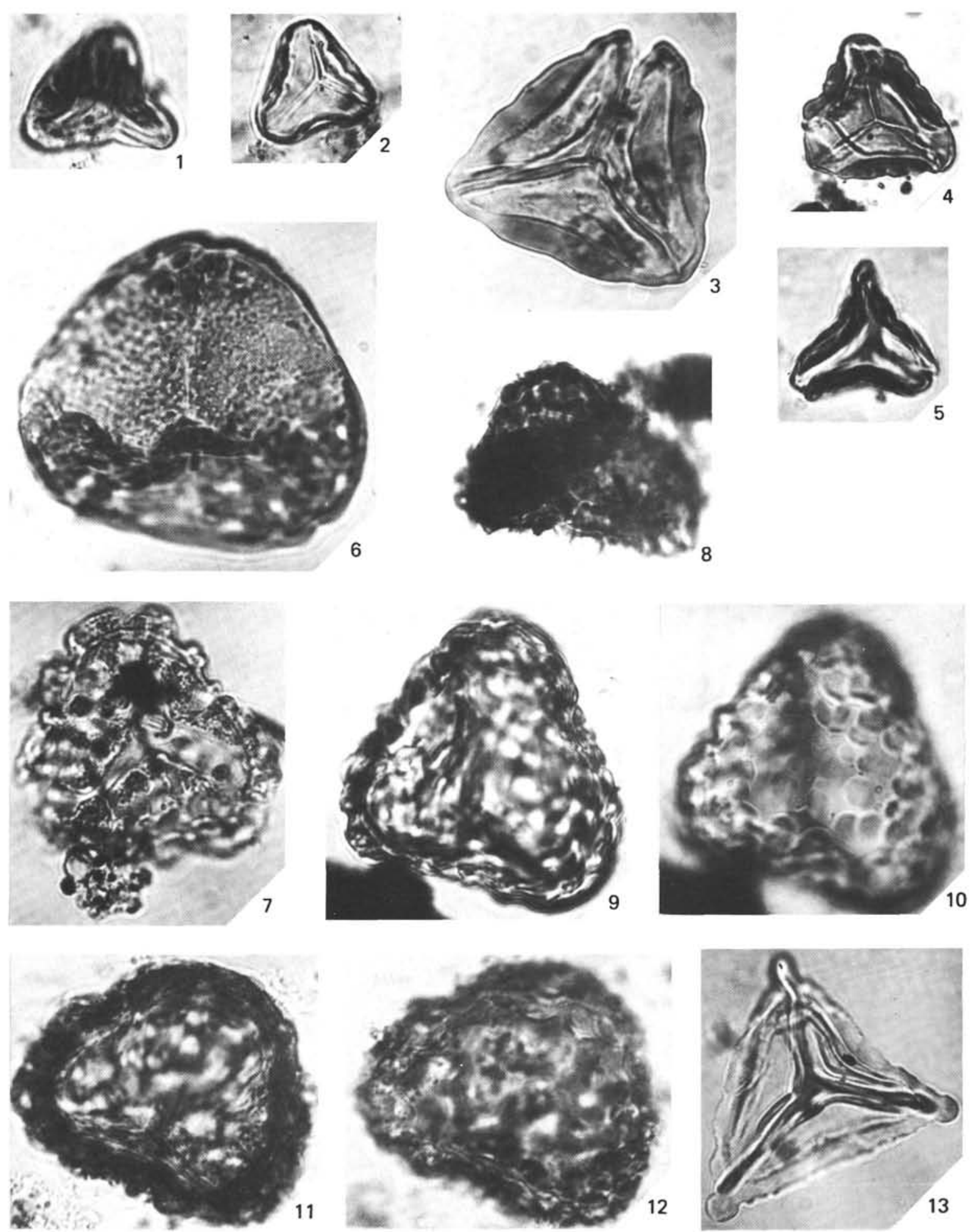

Plate 5. (All specimens magnified $\times 1000$.) 1-2. Gleicheniidites senonicus Ross, 1949 (1) Sample 511-6-3, 40-42 cm (2) Sample 511-16-1, 33-35 cm. 3-4. Gleicheniidites cf. G. trijugatus (Pierce), Burger, 1976 (3) Sample 511-6-2, 40-42 cm, (4) Sample 511-5-3, 20-22 cm. 5. Gleicheniidites circinidites (Cookson), Burger, 1976, Sample 511-6-2, 40-42 cm. 6. Trilobosporites purverulentus (Verbitskaya), Dettmann, 1963, Sample 511-9-4, 92-96 cm. 7. Trilobosporites sp.?, Sample 511-12-1, 25-27 cm. 8. Neoraistrickia sp., Sample 511-5-3, 20-22 cm. 9-10. Trilites cf. paravallatus W. Kr., 1959, Sample 511-4-2, 25-27 cm. 11-12. cf. Trilites sp. 1, Sample 511-6-3, 40-42 cm. 13. Clavifera triplex (Bolkhovitina), Bolkhovitina, 1966, Sample 511-5-1, 20-22 cm. 

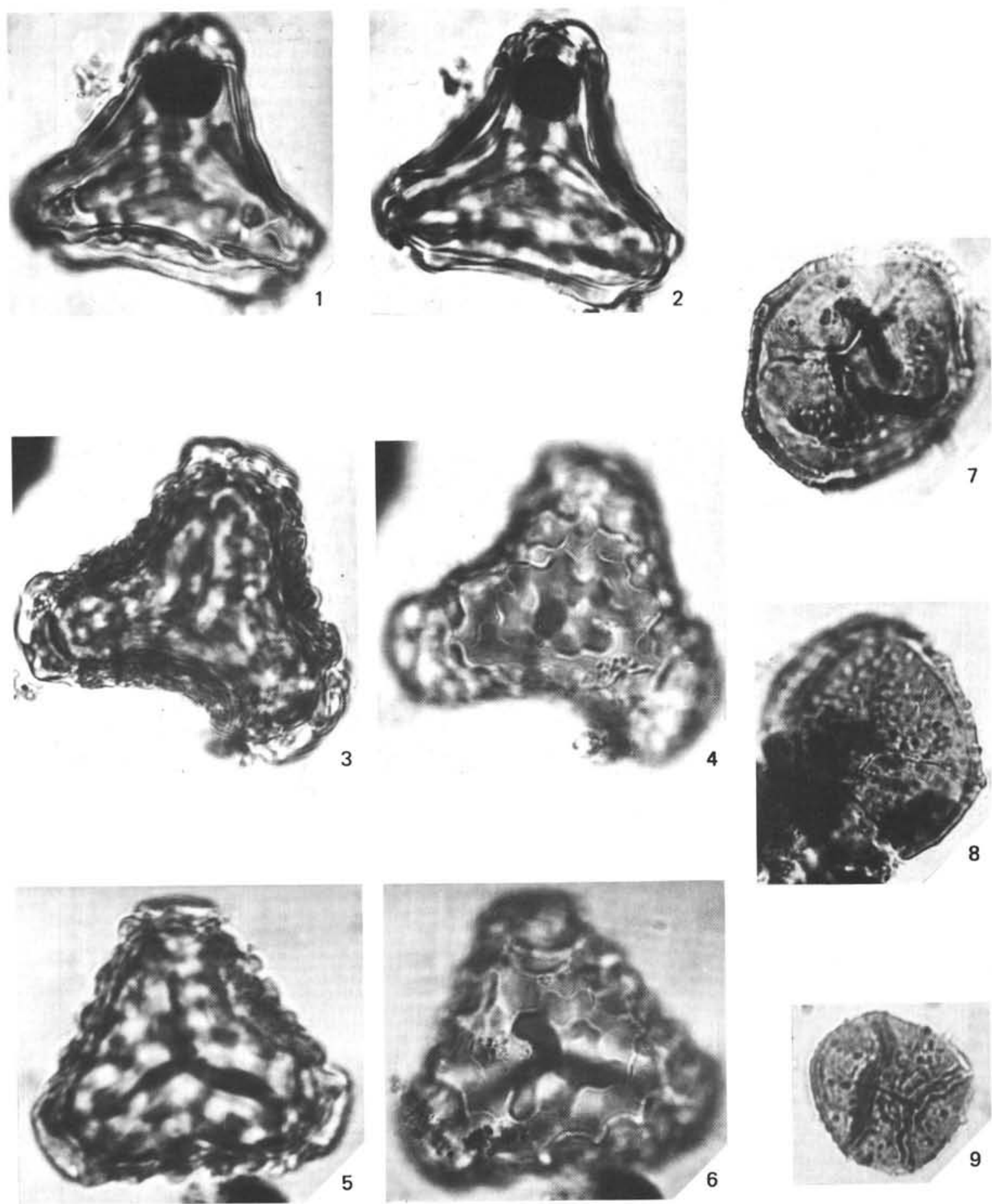

Plate 6. (All specimens magnified $\times 1000$.) 1-2. cf. Trilites sp. 2, Sample 511-12-1, 25-27 cm. 3-4. Dicksonia aff. squarrosa Swartz, Sample 511-12-1, 25-27 cm. 5-6. Dicksonia sp., Sample 511-6-3, 40-42 cm. 7. Foraminisporis dailyi (Cookson and Dettmann), Dettmann, 1963, Sample 511-5-2, 20-22 cm. 8. Foraminisporis wonthaggiensis (Cookson and Dettmann), Dettmann, 1963, Sample 511-12-1, 25-27 cm. 9. Foraminisporis sp., Sample 511-9-7, 42-46. 

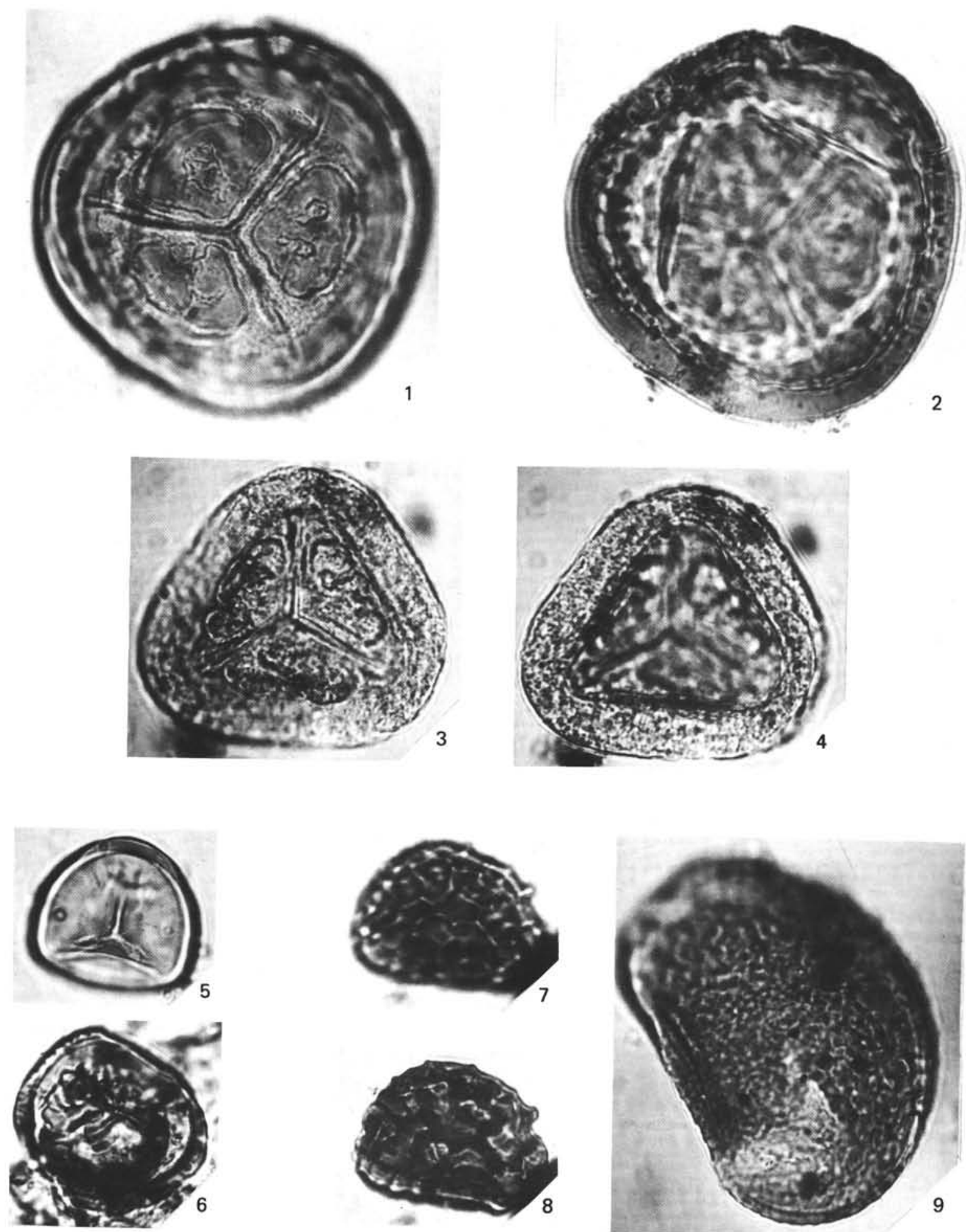

Plate 7. (All specimens magnified $\times 1000$.) 1-2. Cyatheacidites $\mathrm{sp}$. 1, Sample 511-6-2, $40-42 \mathrm{~cm}$. 3-4. Cyatheacidites sp. 2, Sample 511-4-3, $25-27 \mathrm{~cm}$. 5. Cingutriletes australis (Cookson), Archangelsky, 1972, Sample 511-12-1, 25-27 cm. 6. Cingutriletes clavus (Balme), Dettmann, 1972, Sample 511-12-1, 25-27 cm. 7-8. Polypodiidites sp., Sample 511-5-1, 20-22 cm. 9. Polypodiites speciosus (Harris), Archangelsky, 

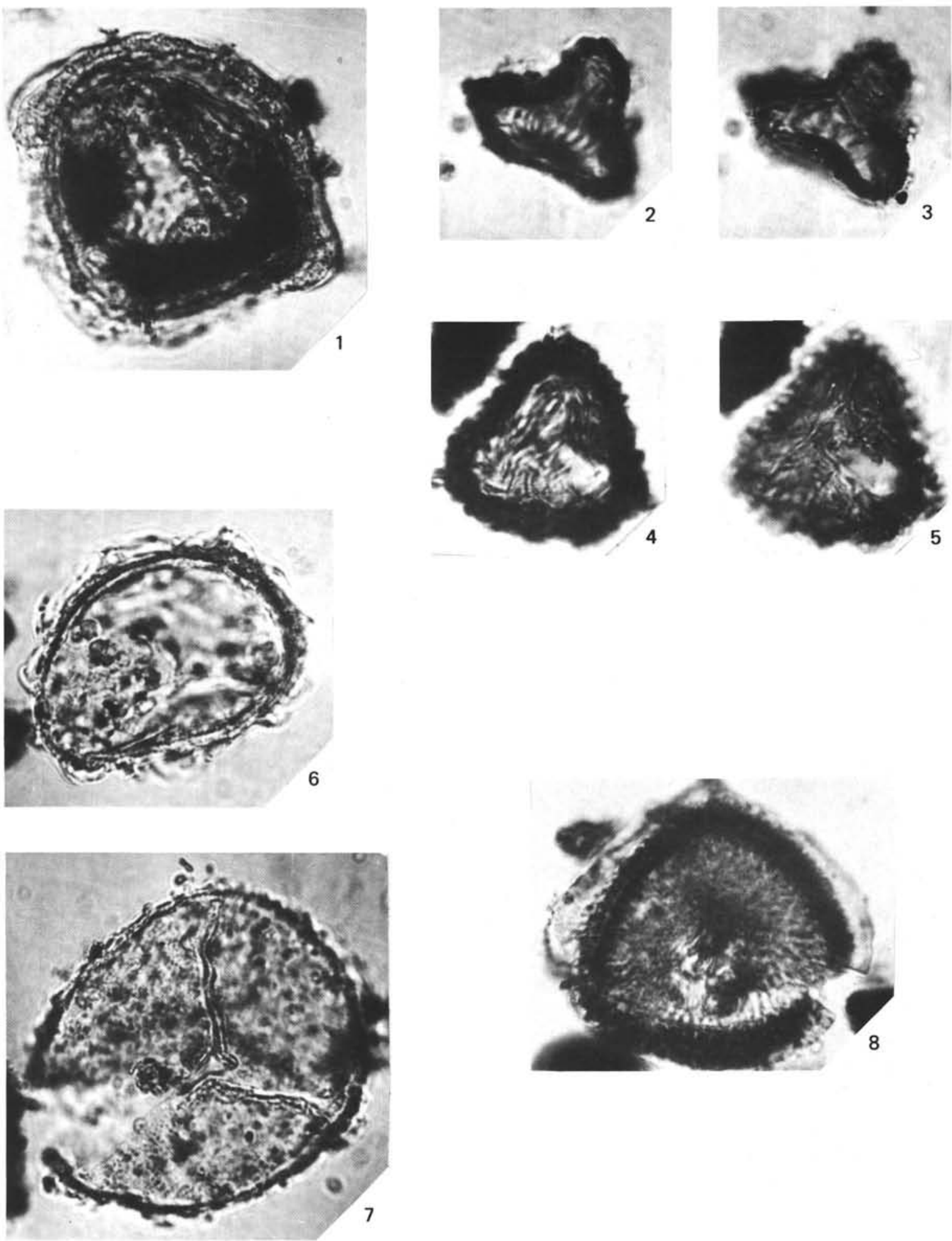

Plate 8. (All specimens magnified $\times 1000$.) 1. Triletes sp. E; Koreneva, 1964, Sample 511-9-4, 92-96 cm. 2-3. Form sp. 1, Sample 511-6-2, 40$42 \mathrm{~cm}$. 4-5. Form sp. 2, Sample 511-5-3, 20-22 cm. 6. Form sp. 3, Sample 511-5-3, 20-22 cm. 7. Form sp. 4, Sample 511-5-3, 20-22 cm. 8. Aequitriradites sp., Sample 511-6-3, $40-42 \mathrm{~cm}$. 

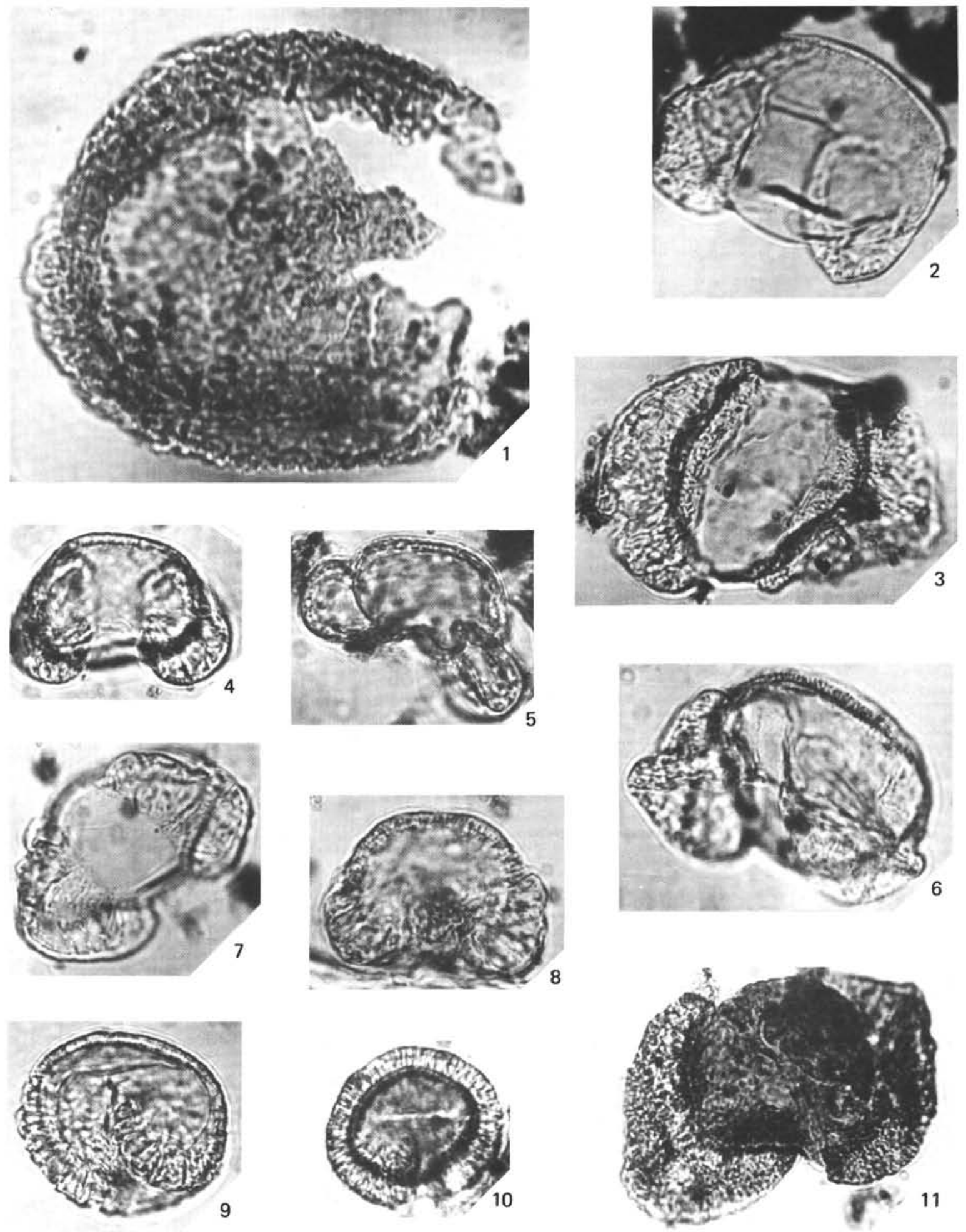

Plate 9. (All specimens magnified $\times 1000$.) 1. Tsugaepollenites $\mathrm{sp}$., Sample 511-5-2, 20-22 cm. 2. Pinuspollenites sp., Sample 511-6-2, 40-42 $\mathrm{cm}$. 3. Podocarpidites marwickii Couper, 1953, Sample 511-6-2, 40-42 cm. 4-5. Podocarpidites elegans Romero, 1977 Sample 511-6-2, 40-42 cm. 6. Podocarpidites microreticuloidata Cookson, 1947, Sample 511-6-2, 40-42 cm. 7. Dacrydiumites sp., Sample 511-5-2, 20-22 cm. 8-9. Dacrydium cupressinum Soland. ex Forst. (8) Sample 511-6-2, 40-42 cm, (9) Sample 511-5-4, 20-22 cm. 10. Dacrydium aff. cupressinum Soland. ex Forst., Sample 511-9-7, 42-46 cm. 11. Podocarpidites sp., Sample 511-4-2, 25-27 cm. 

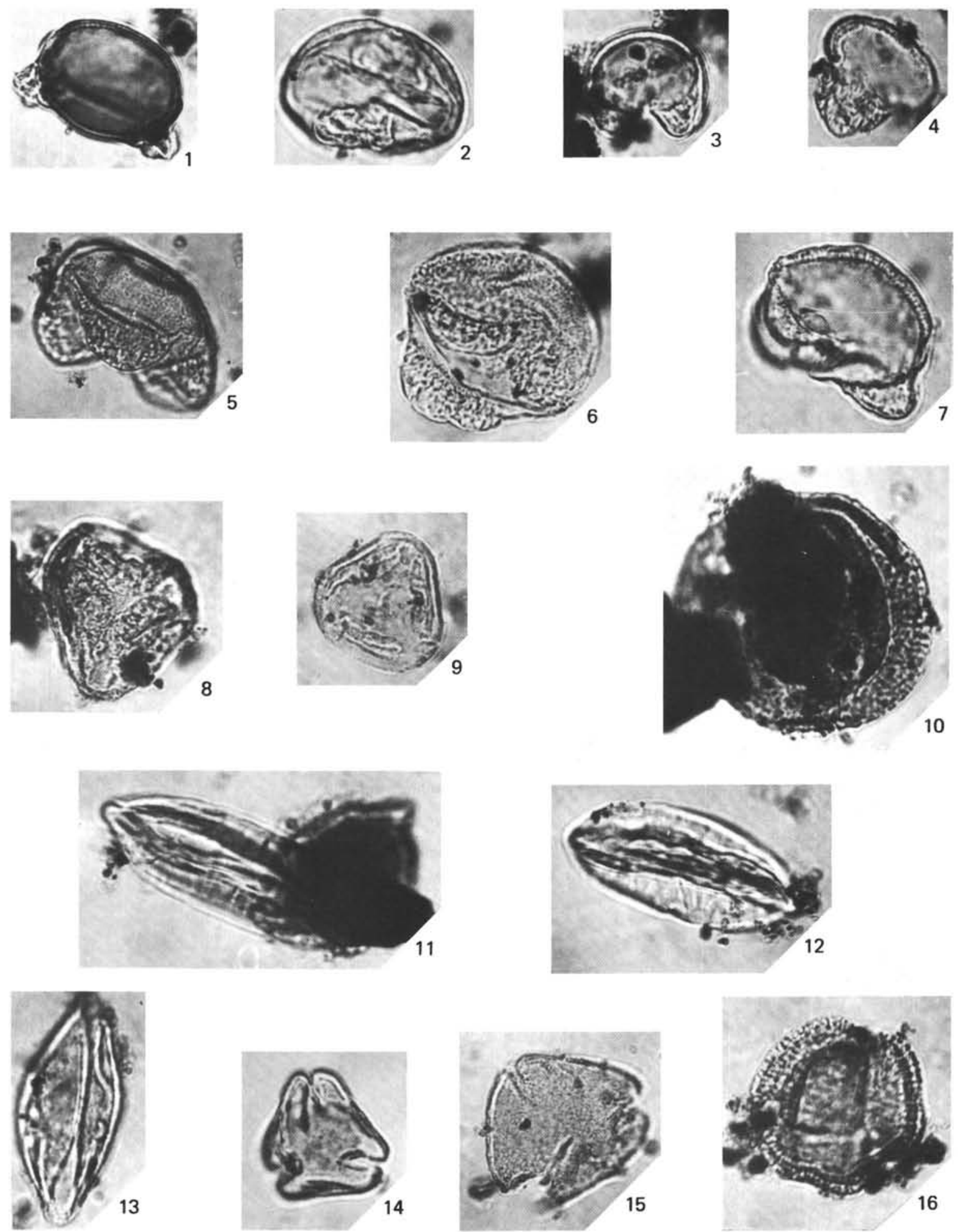

Plate 10. (All specimens magnified $\times 1000$.) 1. Phyllocladidites mawsonii Cookson, 1947, Sample 511-16-1, 33-35 cm. 2. Phyllocladidites mawsonii cf. verrucosus Cookson, 1947, Sample 511-6-2, 40-42 cm. 3-4. Phyllocladidites sp. (3) Sample 511-4-3, 25-27 cm, (4) Sample 5116-2, 40-42 cm. 5-6. Microcachrydites antarcticus Cookson, 1947 (5) Sample 511-11-3, 40-44 cm, (6) Sample 511-5-2, 20-22 cm. 7. Microcachrydites parvus Couper, 1960, Sample 511-6-2, 40-42 cm. 8. Trisaccites microsaccatus (Couper), Couper, 1960, Sample 511-6-2, 40-42 $\mathrm{cm}$. 9. Trisaccites sp., Sample 511-5-2, 20-22 cm. 10. Araucariacites sp., Sample 511-6-2, 40-42 cm. 11-12. Ephedra sp. (11) Sample 511-3-1, 74-76 cm, (12) Sample 511-4-2, 25-27 cm. 13. Monosulcites sp., Sample 511-6-2, 40-42 cm. 14-15. "Tricolpites" cf. gillii Cookson, 1957 (14) Sample 511-12-1, 25-27 cm, (15) Sample 511-9-3, 92-96 cm. 16. Tricolpites alveolatus Couper, 1953, Sample 511-6-2, 40-42 cm. 

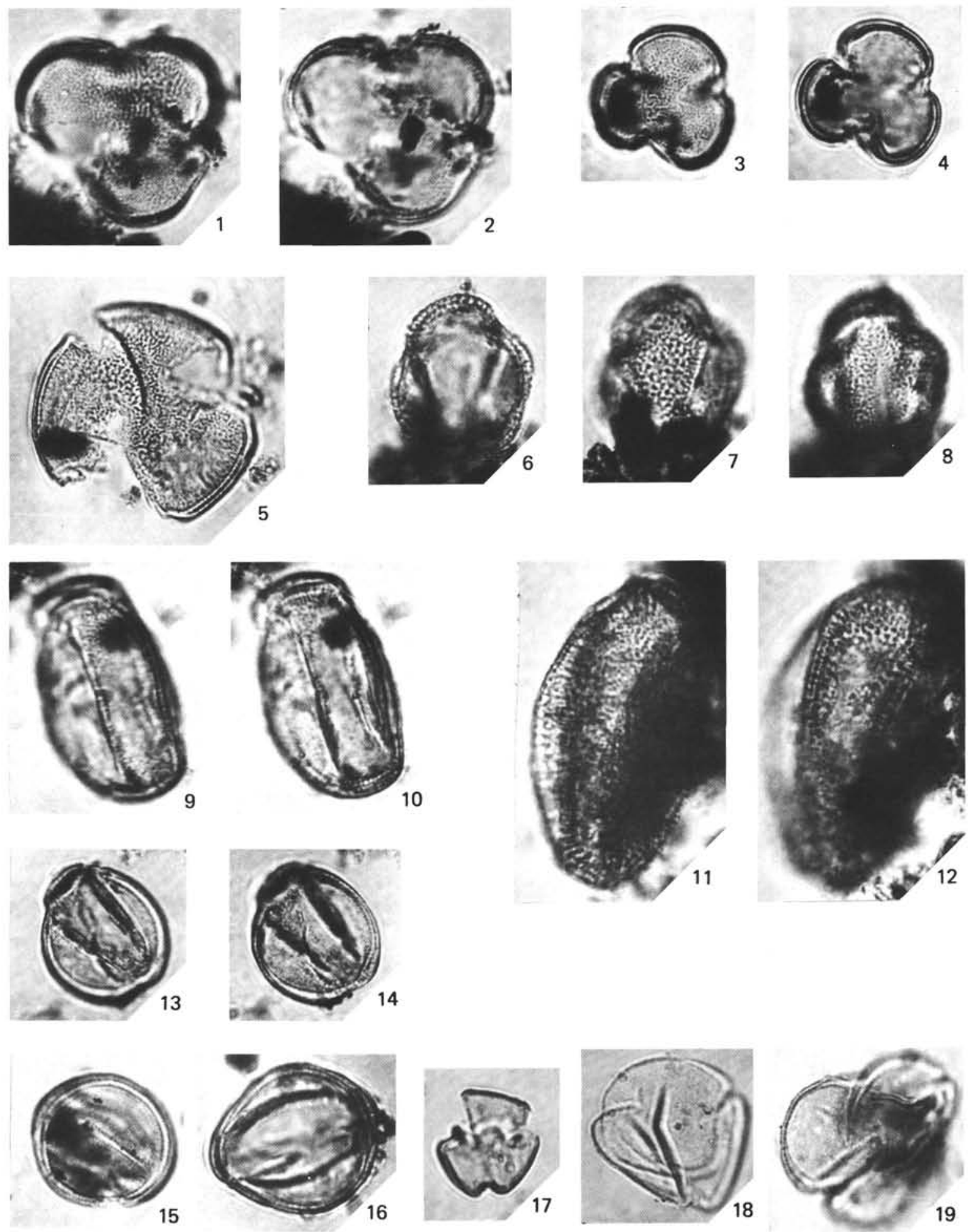

Plate 11. (All specimens magnified $\times 1000$.) 1-2. Tricolpites brevicolpus Couper, 1960, Sample 511-12-1, 25-27 cm. 3-4. Tricolpites cf. brevicolpus Couper, 1960, Sample 511-16-1, 33-35 cm. 5. Tricolpites fissilis Couper, 1960, Sample 511-16-1, 33-35 cm. 6-8. Tricolpites waiparaensis Couper, 1960, Sample 511-6-1, 40-42 cm. 9-10. Tricolpites sp. 1, Sample 511-6-3, 40-42 cm. 11-12. Tricolpites sp. 2, Sample 511-6-3, 40-42 cm. 13-14. Tricolpites sp. 3, Sample 511-16-1, 33-35 cm. 15-16. Tricolpites sp. 3 (15) Sample 511-6-4, 40-42 cm, (16) Sample 511-6-2, 40-42 cm. 17. Tricolpites sp. 4, Sample 511-5-2, 20-22 cm. 18-19. Tricolpites sp. 5 (18) Sample 511-9-7, 42-46 cm, (19) Sample 511-5,CC. 

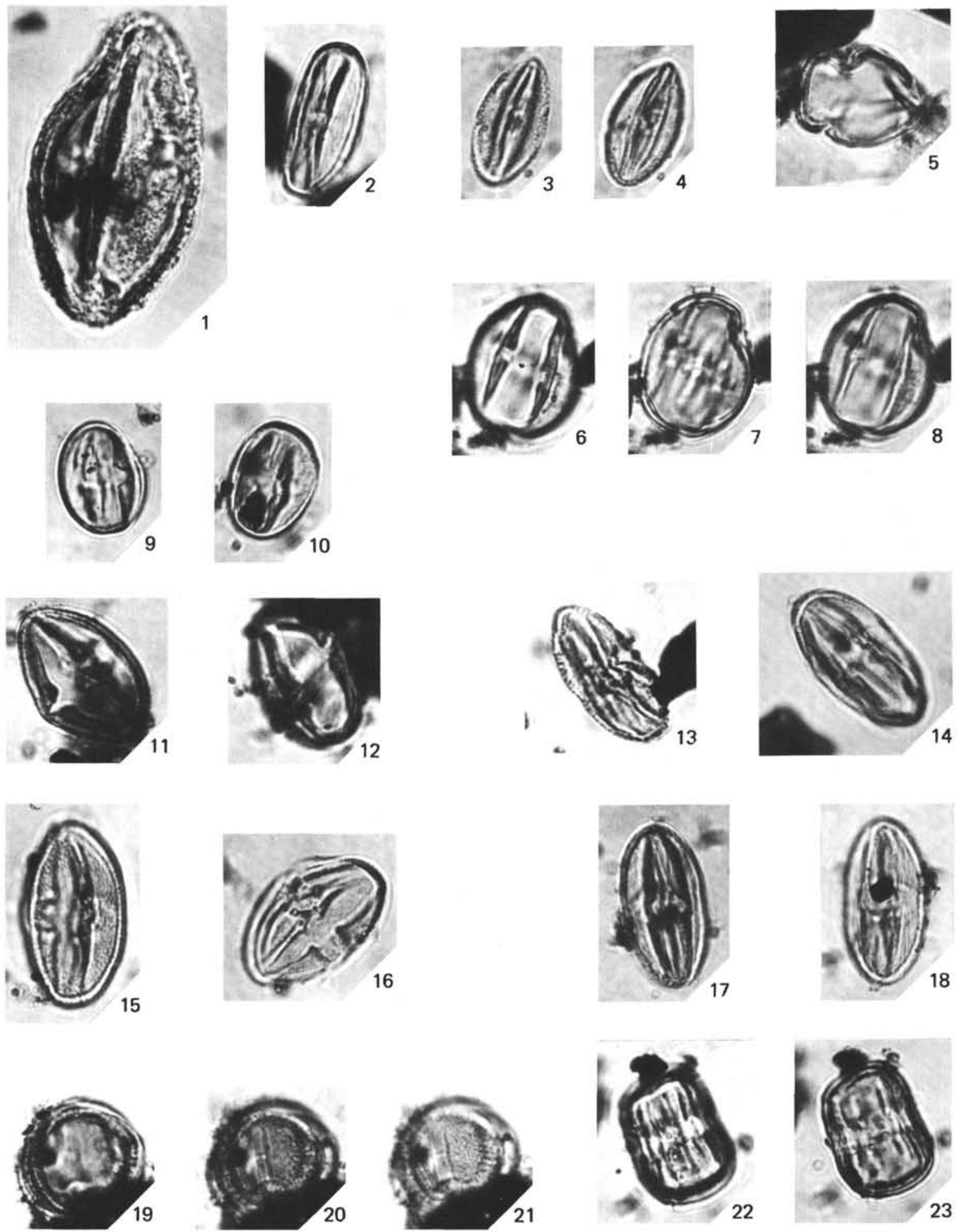

Plate 12. (All specimens magnified $\times$ 1000.) 1. Tricolporopollenites $\mathrm{sp} .1$, Sample $511-12-1,25-27 \mathrm{~cm} . \quad$ 2. Tricolporopollenites sp. 2, Sample 511-6-2, 40-42 cm. 3-4. Tricolporopollenites sp. 3, Sample 511-9-3, 92-96 cm. 5. Tricolporopollenites sp. 4, Sample 511-6-2, 40-42 $\mathrm{cm}$. 6-8. Tricolporites scabratus Harris, 1965 , Sample $511-9-3,92-96 \mathrm{~cm}$. 9-10. Psilatricolporites sp. (9) Sample 511-6-2, 40-42 cm, (10) Sample 511-6-4, 40-42 cm. 11-12,. Rhoipites communis Sah, 1967 (11) Sample 511-6-2, 40-42 cm, (12) Sample 511-6-2, 40-42 cm. 13-14. Rhoipites baculatus Archangelsky, 1973 (13) Sample 511-5-2, 20-22 cm, (14) Sample 511-9-4, 92-96 cm. 15-16. Rhoipites striatoreticulatus Sah, 1967 (15) Sample 511-6-2, 40-42 cm, (16) Sample 511-5-2, 20-22 cm. 17-18. Rhoipites sp., Sample 511-6-2, 40-42 cm. 19-21. Senipites cf. tercrassata Archangelsky, 1973, Sample 5,CC. 22-23. Tetracolporites sp., Sample 511-5-2, 20-22 cm. 

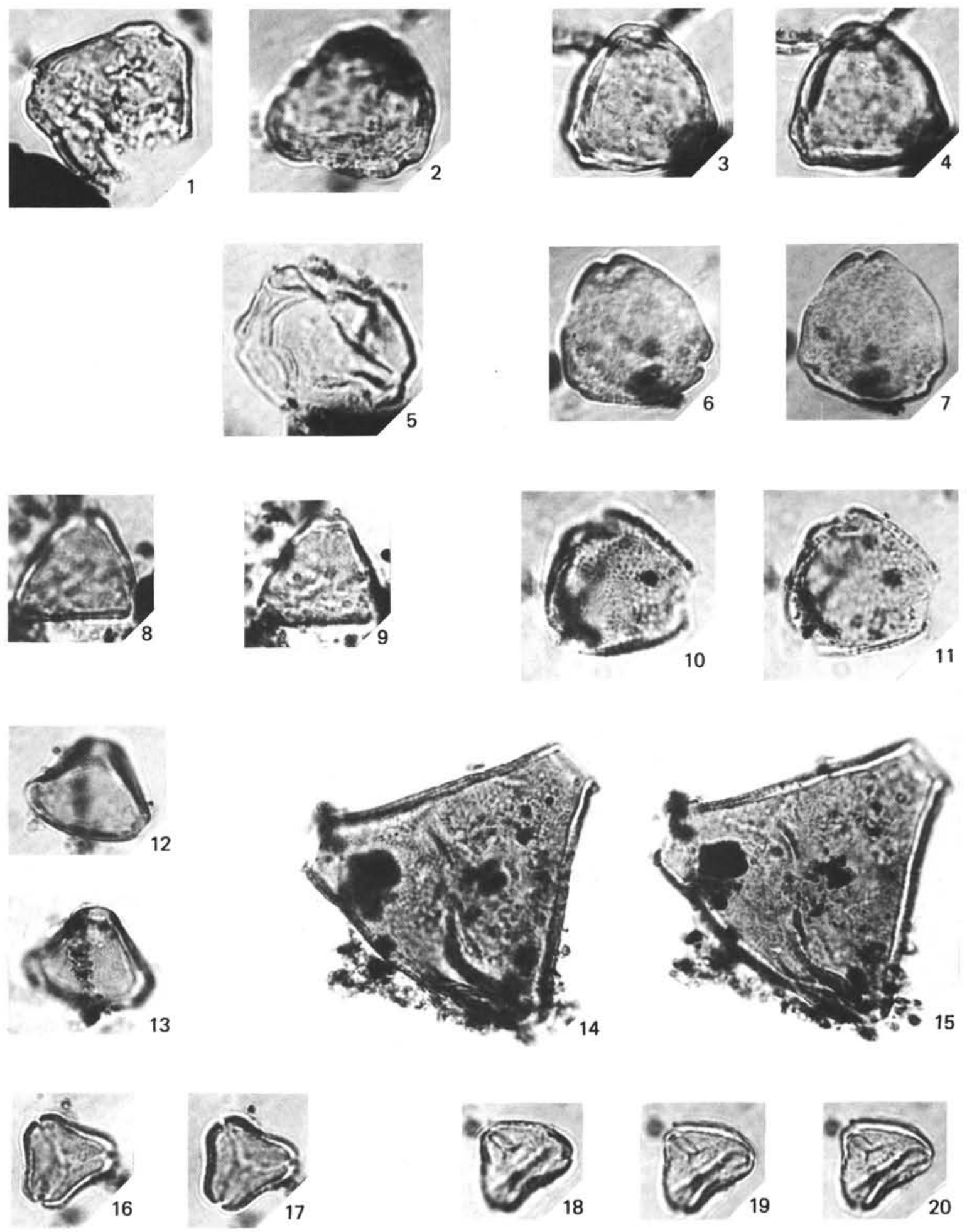

Plate 13. (All specimens magnified $\times 1000$.) 1-2. Triorites harrisii Couper, 1953 (1) Sample 511-12-1, 25-27 cm, (2) Sample 511-12-2, 25-27 cm. 3-4. Casuarinidites cainozoicus Denmark, Sample 511-6-2, 40-42 cm. 5-7. Casuarinidites sp. (5) Sample 5,CC, (6-7) Sample 511-6-2, 40-42 $\mathrm{cm}$. 8-9. Proteacidites minimus Couper, 1954, Sample 511-5-2, 20-22 cm. 10-11. Proteacidites cf. retiformis Couper, 1960, Sample 511-4-3, 25-27 cm. 12-13. Proteacidites sp., Sample 511-5-1, 20-22 cm. 14-15. Proteacidites rectomarginis Cookson, 1950, Sample 511-6-1, 40-42 cm. 16-17. Myrtaceidites sp., Sample 511-5-2, 20-22 cm. 18-20. Myrtaceidites parvus forma nesus Cookson and Pike, 1954, Sample 511-5-3, $20-22 \mathrm{~cm}$. 

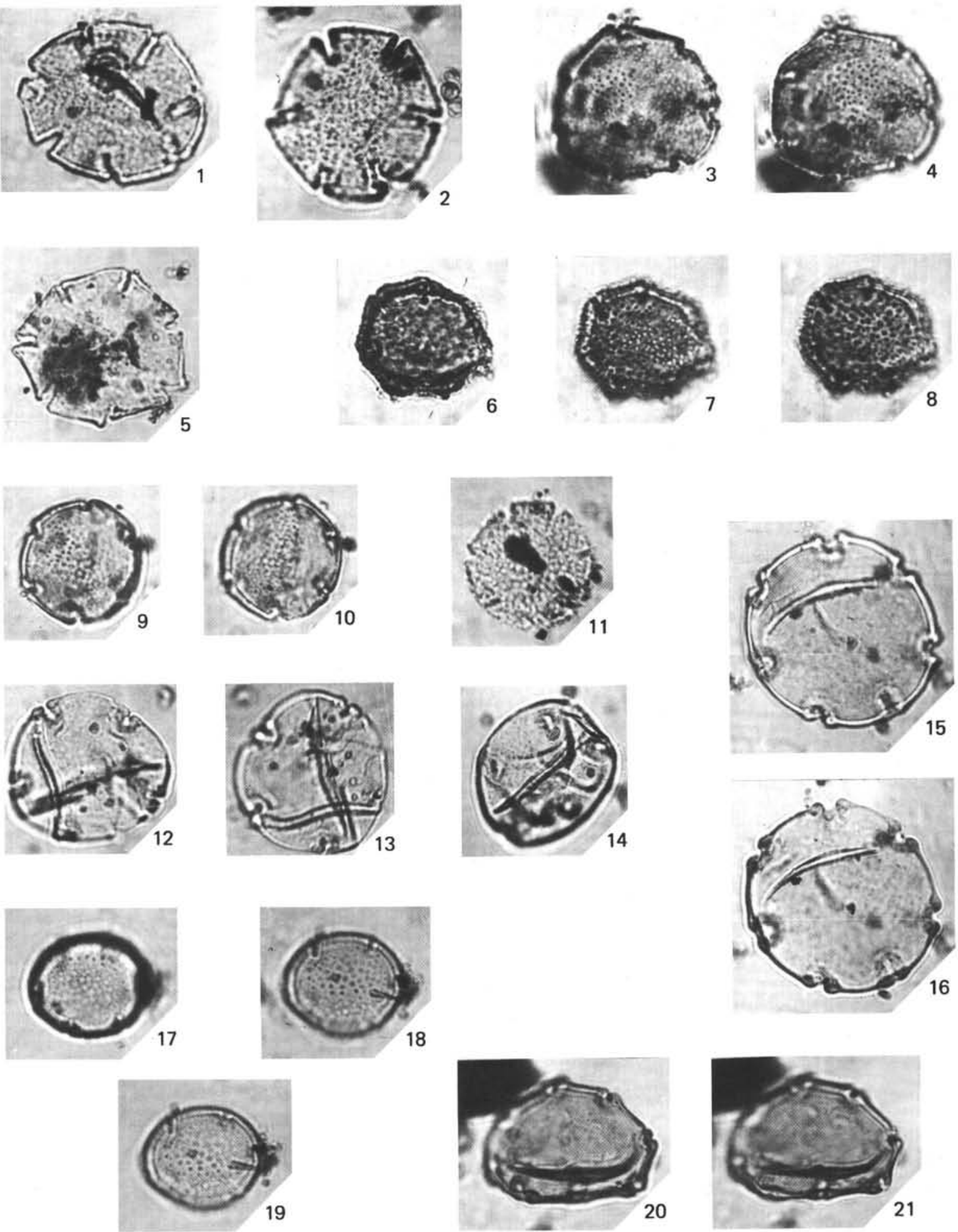

Plate 14. (All specimens magnified $\times 1000$.) 1-2. Nothofagidites asperus (Cookson), Romero, 1973 (1) Sample 511-12-2, 25-27 cm, (2) Sample 511-5-2, 20-22 cm. 3-4. Nothofagidites deminuta (Cookson), Romero, 1977, Sample 511-5-1, 20-22 cm. 5. Nothofagidites cranwellae (Couper), Fasola, 1969, Sample 511-6-2, 40-42 cm. 6-8. Nothofagidites spinosus Couper, 1960, Sample 511-6-2, 40-42 cm. 9-10. Nothofagidites brachispinulosa (Cookson), Harris, 1965, Sample 511-5-2, 20-22 cm. 11. Nothofagidites sp. 1, Sample 511-6-2, 40-42 cm. 12-14. Nothofagidites sp. 2 (12-13) Sample 6-2, 40-42 cm, (14) Sample 511-16-1, 33-35 cm. 15-16. Nothofagidites cincta (Cookson), Fasola, 1969, Sample 511-9-3, 93-96 cm. 17-19. Nothofagidites sp. 3, Sample 511-5-2, 20-22 cm. 20-21. Nothofagidites sp. 4, Sample 511-5-2, 20-22 cm. 

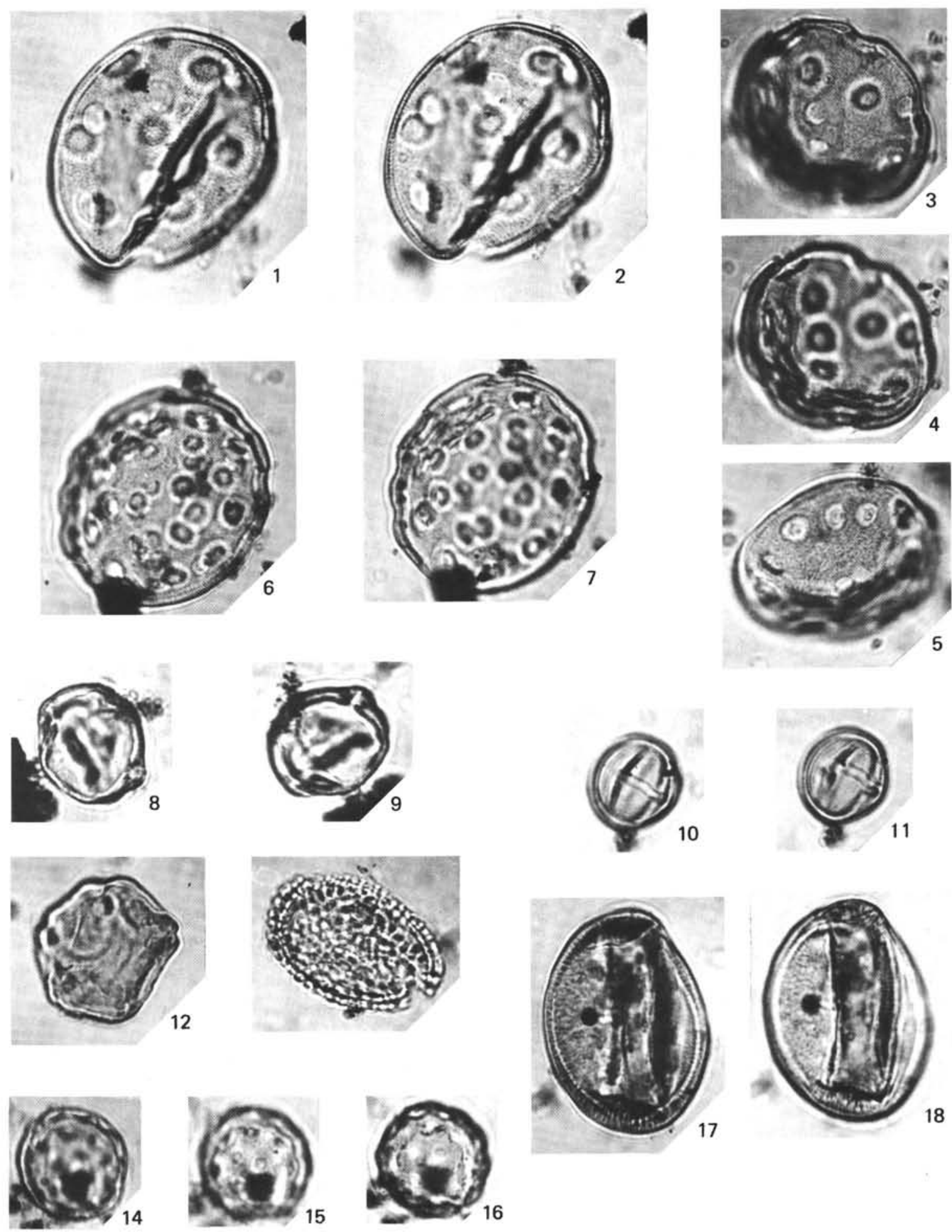

Plate 15. (All specimens magnified $\times 1000$.) 1-5. Parsonsidites $\mathrm{cf}$. psilatus Couper, 1960 (1-2) Sample 511-5-1, 20-22 cm. (3-5) Sample 5116-3, 40-42 cm. 6-7. Parsonsidites cf. conspicuus Frederiksen, 1973, Sample 511-5-2, 20-22 cm. 8-9. Rhizophora sp. 1, Sample 511-9-3, 92-96 cm. 10-11. Rhizophora sp. 2, Sample 511-5-1, 20-22 cm. 12. Alnus sp., Sample 511-12-1, 25-27 cm. 13. Ilex sp., Sample 511-5-1, 20-22 cm. 14-16. Chenopodiaceae, Sample 511-5,CC. 17-18. Polygonum sp., Sample 511-9-4, 92-96 cm. 

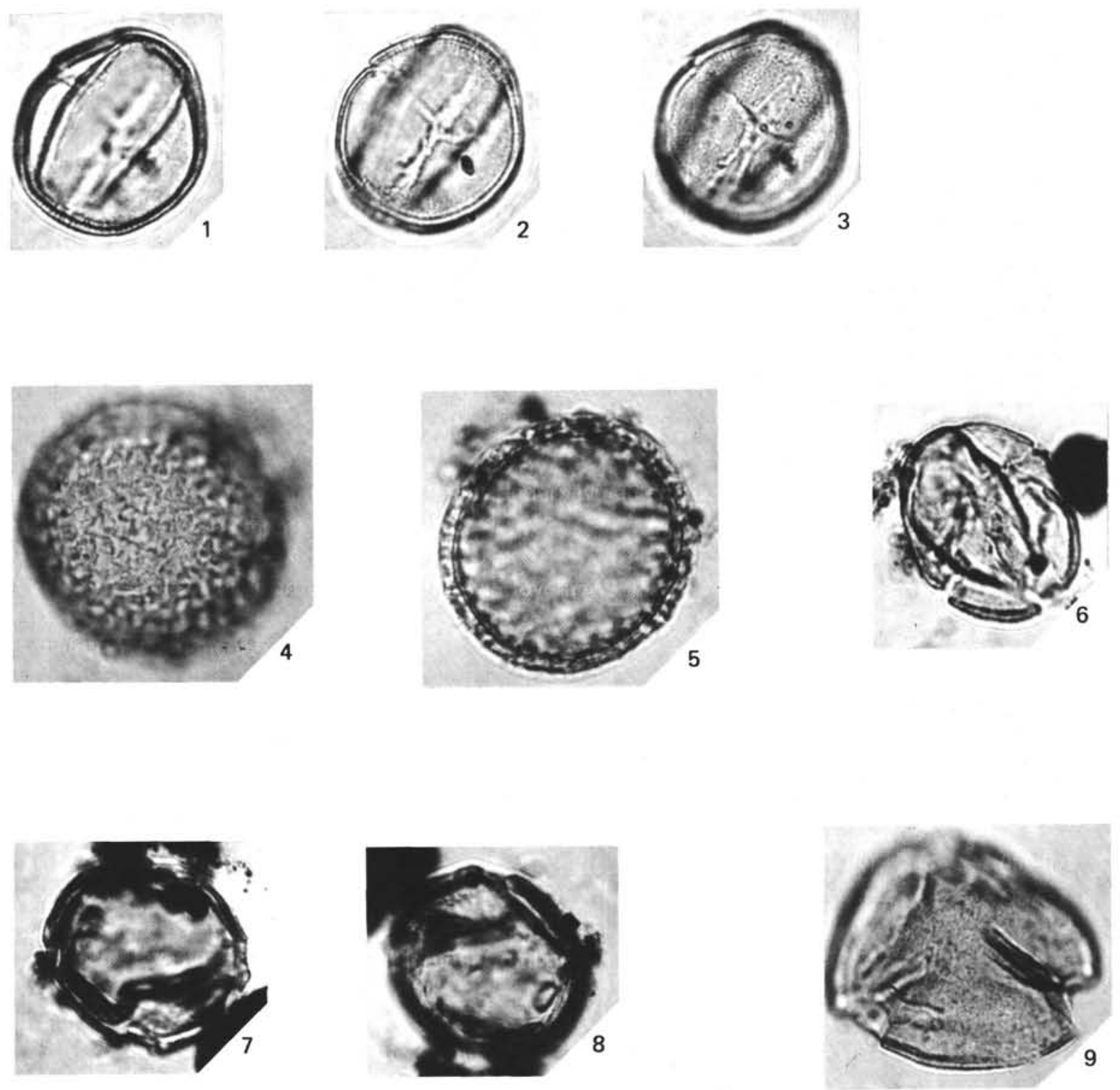

Plate 16. (All specimens magnified $\times 1000$.) 1-3. Form sp. 1, Sample 511-6-2, 40-42 cm. 4-5. Form sp. 2, Sample 511-9-7, 42-46 cm. 6 . Form sp. 3, Sample 511-9-4, 92-96 cm. 7-8. Form sp. 4, Sample 511-5-4, 20-22 cm. 9. Form sp. 5, Sample 511-9-7, 42-46 cm. 

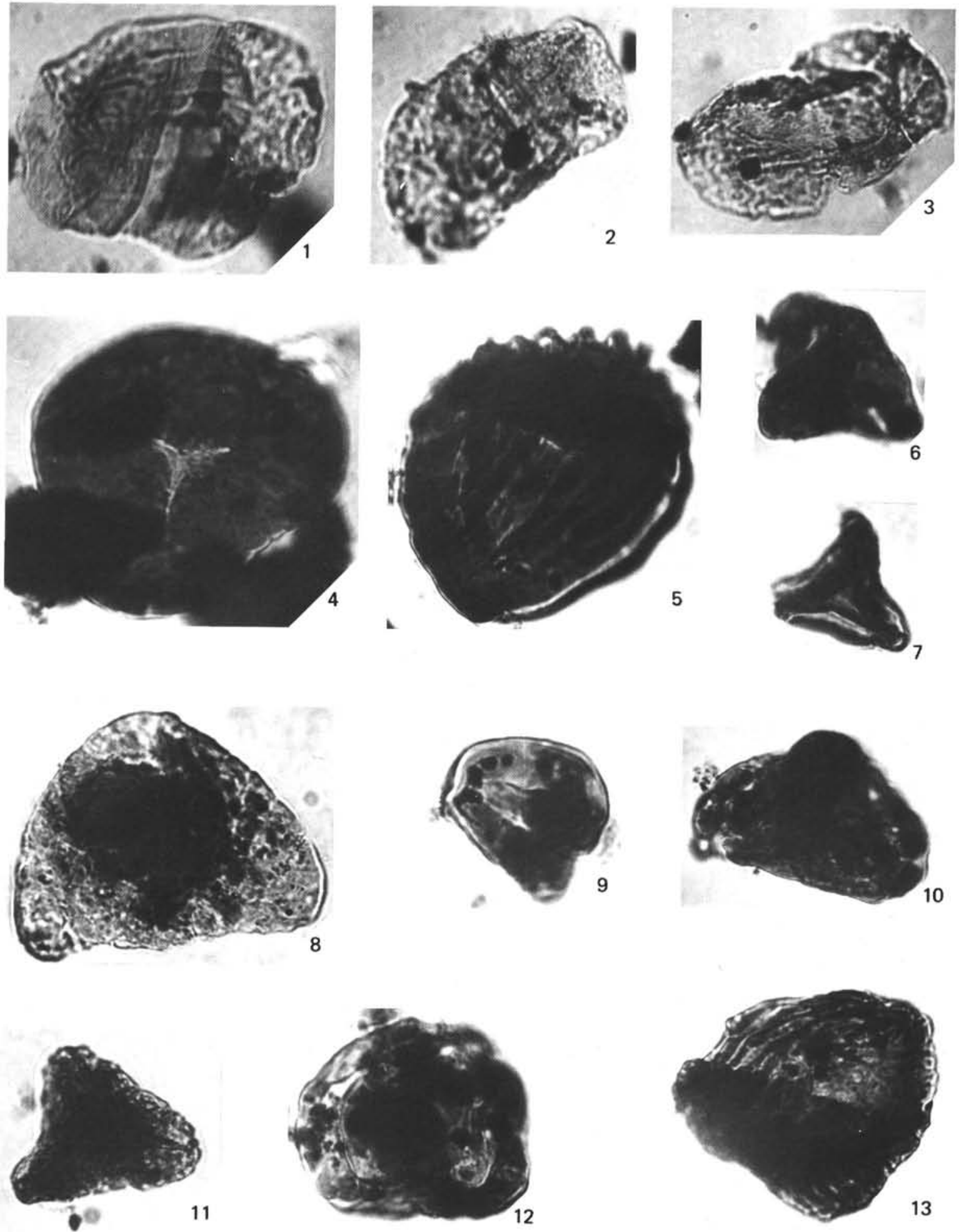

Plate 17. (All specimens magnified $\times 1000$.) 1-3. Striate pollen (1) Sample 511-4-2, 25-27 cm, (2) Sample 511-5-4, 20-22 cm, (3) Sample 511-4-3, $25-27 \mathrm{~cm}$. 4. Leiotriletes?, Sample 511-5-2, 20-22 cm. 5. Cicatricosisporites sp., Sample 511-6-2, 40-42 cm. 6-7. Gleicheniidites? (6) Sample 511-6-2, 40-42 cm, (7) Sample 511-5-4, 20-22 cm. 8-12. Spore? (8) Sample 511-5,CC, (9) Sample 511-9-3, 92-96 cm, (10) Sample 511-11-3, 40-44 cm, (11) Sample 511-9-2, 92-96 cm, (12) Sample 511-6-1, 40-42 cm. 13. Cicatricosisporites sp., Sample 511-6-2, 40-42 cm. 